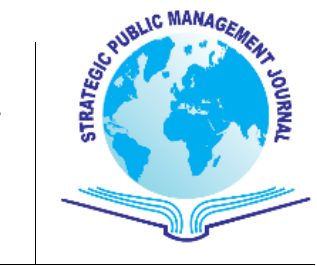

\section{Van Kent Merkezi ve Yakın Çevresinde Yeşil Altyapı Bileșenlerinin CBS Araçları ile Tanımlanması}

Identification of Green Infrastructure Components via GIS Tools for Van City and Near Surroundings

Ayşe DEMİR ${ }^{1}$

Emel BAYLAN ${ }^{2}$
Strategic Public Management Journal Issue 9 , pp. 79/108 May 2019 DOI: $10.25069 /$ spmj.505466 Received:30/12/2018 Accepted:02/04/2019 (C) The Author(s) 2017 For reprints and permissions: http://dergipark.gov.tr/spmj

\title{
$\ddot{O} z$
}

Nüfus artışı ve kentsel yayılmanın baskısıyla doğal peyzajların parçalanması sonucu ortaya çıkan habitat ve biyoçeşitlilik kaybını önlemek ve ekosistem işlevlerinin zarar görmesini engellemek amacı ile 20. yüzyılın ortalarından itibaren ekolojik ağlar, yeşil koridorlar ve yeşil altyapı gibi mekansal planlama yaklaşımları geliştirilmiştir. Yeşil altyapı planlama ve tasarım süreci; ekosistem hizmetlerinin doğadan insana ulaşmasını ve doğal kaynakların koruma-kullanım dengesinin gözetilmesini temel alan, sürdürülebilirlik odaklı çözümleri hedefleyen bir yaklaşımdır. Yeşil altyapı sistemi, parklar, bahçeler, tarım alanları, sulak alanlar, ormanlar, yol ăgaçlıkları, akarsular, doğal rezerv alanları, tarihi alanlar, göller gibi farklı özellikte ve farklı boyutlardaki doğal ve kültürel alanları içerir. Bu alanlar birbiriyle, merkez (çekirdek), bağ (koridor) ve alan olarak tanımlanan yeşil alt yapı bileşenleri ile ile birbirine bağlanmaktadır. Bu bildirinin amacı; Van Kent merkezinde ve yakın çevresinde, Coğrafi Bilgi Sistemleri kullanılarak belirlenen yeşil alt yapı bileşenlerinin mevcut durumunun saptanmasıdır. Bu kapsamda, alanda yer alan doğal ve kültürel peyzaj öğeleri ARCGIS 10.2'de Spatial Analyst ve 3D Analyst araçları ile analiz edilerek Van Kent Merkezi ve yakın çevresinin yeşil altyapı bileşenleri bakımından mevcut durumu ortaya konmuştur.

Anahtar kelimeler: Yeşil Altyapı, Coğrafi Bilgi Sistemleri, Çekirdek, Doğal ve Kültürel Peyzaj Öğeleri.

\begin{abstract}
In the mid-20th century, spatial planning approaches such as ecological networks, green corridors and green infrastructure have been developed in order to prevent the loss of habitat and biodiversity resulting from the fragmentation of natural landscapes with the pressure of population growth and urban expansion. Green infrastructure planning and design process; It is an approach that targets sustainability-oriented solutions, based on the protection of ecosystem services from nature to people and observing the balance of conservationuse of natural resources. Green infrastructure system, parks, gardens, agricultural areas, wetlands, forests,
\end{abstract}

\footnotetext{
${ }^{1}$ Ankara Üniversitesi, Fen Bilimleri Enstitüsü, Peyzaj Mimarlığı Anabilim Dalı, aysedemir566@ hotmail.com

${ }^{2}$ Dr. Öğr. Üyesi, Yüzüncü Yıl Üniversitesi, Mimarlık ve Tasarım Fakültesi, Peyzaj Mimarlığı Bölümü, emelbaylan@yyu.edu.tr
} 
road woodlands, rivers, natural reserve areas, historical areas, lakes, natural and cultural areas of different sizes and different sizes include. These areas are connected to each other by means of green substructure components, which are defined as core (cores), vineyards and spaces. The purpose of this paper is; Determining the current state of the green infrastructure components determined by using Geographical Information Systems in and around Van city center. In this context, the natural and cultural landscaping elements in the area were analyzed in ARCGIS 10.2 by means of Spatial Analyst and 3D Analyst tools and the current situation of Van City Center and its close surroundings in terms of green infrastructure components was revealed.

Key words: Green Infrastructure, Geographic Information Systems, Core, Natural and Cultural Landscape Elements.

\section{GíRiş}

Arazi kullanım eğilimleri ve planlama stratejileri coğrafyaya göre değişse de artan kentsel yayılma, ulaşım ağları, enerji nakil hatları ve su kıyılarının doldurulması gibi süreçler, doğal alanların, ekosistemlerin karşı karşıya kaldıkları baskıları artırmakta, bu alanlara zarar vermekte ve hatta kaybedilmesi ile sonuçlanmaktadır. Özellikle sanayi devriminden sonra Dünya genelinde kentleşme ve kentsel nüfus hızla artış göstermiştir (Sandstrom, 2002:373-385). Nüfus artışı ve buna bağlı olarak artan insan ihtiyaçları beraberinde, sanayileşme, iklim değişikliğgi; doğal ve kültürel peyzaj öğelerine ekosistemlere ve ekosistemler arasındaki ekolojik süreçlere zarar vermektedir (Ahern, 1995:131-155).

Kentsel arazi kullanım kararlarında ve uygulamalarında doğal kaynak koruma ve kullanım dengesinin gözardı edilmesi, peyzajın yapısının bozulmasına, doğal ve kültürel peyzajların ekosistem işlevlerinin bozulmasına, türlerin doğal yaşamlarından izole olmasına yani habitatların parçalanmasına sebep olmaktadır (Andersson ve ark., 2014: 445-453). Kentleşme sürecindeki alanlarda habitat parçalanması sonucu, tür hareketi sınırlanmakta bu sebepten ötürü ekosistemler arasındaki besin alışverişi engellenmektedir. Tüm bu süreçler zamanla biyoçeşitliliğin azalmasına ve önlem alınmadığı takdirde yok olmasına sebep olmaktadır (Coşkun Hepcan, 2008:13; Anderson ve ark., 2014:445-453; Civic ve Siuta, 2014:6-15). Türlerin izole olmas1 sonucu oluşan habitat parçalanması, biyoçeşitliliğin azalması ve zamanla yok olması, ekosistem süreçlerinin zarar görmesi farklı yoğunluklarda ve biçimlerde olmakla birlikte dünya genelinde, kentleşme baskısı altındaki tüm doğal ve kültürel peyzajlarda karşılaşılan bir sorundur (Bennett, 2004:7-15; Coşkun Hepcan, 2008:9). Bu süreçler ve sonuçlar, kentlerde canlıların yaşam kalitesini olumsuz etkilemekte ve kentlerin canlılar için yaşanabilirliğini ve sürdürülebilirliğini tehdit etmektedir (Anderson ve ark., 2014:449).

Günümüzde kentlerin doğal ve kültürel peyzaj öğeleri bakımından sürdürülebilirliği, yakın çevresindeki ve hatta daha da uzak peyzajların sürdürülebilirliği için vazgeçilmezdir (Wu, 2013:1002). Bu bağlamda kentsel alanların doğal kaynaklar bakımından sürdürülebilirliği ve kentsel yaşam kalitesinin iyileştirilmesi için, kent içindeki ve yakın çevresindeki doğal ve kültürel peyzaj öğelerinin ve kenti kullanan canlılar arasında bağlantının kurulmasına ve güçlendirilmesine yardımcı olacak peyzaj planlama yaklaşım ve araçlarına ihtiyaç duyulmaktadır. Bu ihtiyaç karşısında, habitat parçalanmasına bağlı olarak oluşan tür kaybını engellemek ve ekosistem süreçlerinin zarar görmesini engellemek amacıyla 20. yüzyılın ortalarından itibaren farklı planlama yaklaşım ve stratejileri kullanılmıştır (Bennett, 2004:7-15; Coşkun Hepcan, 2008:3). Mevcut koruma stratejilerine alternatif olarak geliştirilen planlama yaklaşım ve stratejilerinden olan ekolojik ağlar, yeşil koridorlar, yeşil yollar, yeşil altyapı (YA) çalışmalarının hedefi; doğal ve kültürel peyzajlar arasında bağlantılar 
kurulması ve geliştirilmesidir (Jongman ve Pungetti, 2004:12; Coşkun Hepcan, 2008:4). Bu amaçla geliştirilen planlama yaklaşımları ve stratejileri, parçalanmış habitatlar arasında fiziksel ve işlevsel bağlantıları sağlayarak, peyzajın ekolojik ve kültürel işlev ve yararlarının korunmasını ve iyileştirilmesini amaçlanmaktadır. Sürdürülebilir peyzaj planlama yönetimi ve yaklaşımı ile hazırlanan bu planlama yaklaşımları ve stratejileri aynı zamanda ekosistem süreçlerinin zarar görmesini engellemek, doğal ve kültürel peyzaj öğelerinin korunmasını ve toplumların yaşam kalitesini iyileştirmeyi amaçlamaktadır (Lovell ve Taylor, 2013:1450; Mell, 2009:23-34).

Yeşil altyap1, bulunduğu peyzajın doğal destek sistemi başka bir deyişle doğal peyzajın iskeletini oluşturmaktadır (Weber ve vd., 2006:94-110). Peyzaj ekolojisi, doğal kaynakların sürdürülebilirliğini temel alan, doğal ve kültürel peyzajların farklı işlevleri yerine getirmesini sağlayan planlama ve uygulamaları, habitat bütünlügünü, fiziksel ve kültürel faaliyetleri ve toplumun doğa ile kommünal bağlar kurmasını destekleyen alanlar yaratmaya yöneliktir. Yeşil altyapı sistemi, parklar, bahçeler, tarım alanları, sulak alanlar, ormanlar, yol ağaçlıkları, akarsular, doğal rezerv alanları, tarihi alanlar, göller gibi farklı özellikte ve farklı boyutlardaki doğal ve kültürel alanları içerir (Benedict ve McMahon, 2006:7). Bu alanlar birbirine ile yeşil altyapıdaki merkez (çekirdek), bağ (koridor) ve alan'lar ile birbirine bağlanmaktadır (Şekil 1.1).

Şekil 1.1 Yeşil Altyapı Sistemi Bileşenleri

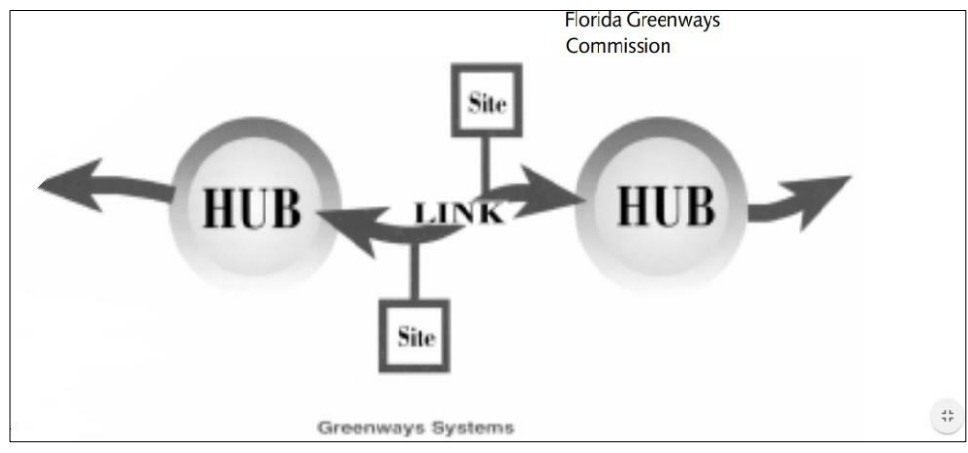

Kaynak: Benedict ve McMahon, 2006:7.

Tablo 1.1 Yeşil Altyapı Bileşenlerine Örnekler

\begin{tabular}{|c|c|c|}
\hline Merkez (Çekirdek) & Bağlantı/ Bağ ( Koridor) & Alan (Leke) \\
\hline $\begin{array}{ll}\text { - } & \text { Doğal rezerv alanları } \\
\text { - } & \text { Mezarlıklar } \\
\text { - } & \text { Vahşi yaşam alanları } \\
\text { - } & \text { Sulak alanlar } \\
\text { - } & \text { Büyük ölçekli parklar } \\
\text { - } & \text { Çiftlikler } \\
\text { - } & \text { Bölgesel ve ulusal parklar }\end{array}$ & $\begin{array}{ll}\text { - } & \text { Akarsular } \\
\text { - } & \text { Nehir yatakları } \\
\text { - } & \text { Yollar } \\
\text { - } & \text { Enerji hatları } \\
\text { - } & \text { Derenaj yolları } \\
\text { - } & \text { Kanallar } \\
\text { - } & \text { Parklar }\end{array}$ & $\begin{array}{ll}\text { - } & \text { Boş araziler } \\
\text { - } & \text { Yerleşim alanları } \\
\text { - } & \text { Sanayi alanları } \\
\text { - } & \text { Atık imha alanları } \\
\text { - } & \text { Karmakullanım bölgeleri } \\
\text { - } & \text { Ticari alanlar } \\
\text { - } & \text { Yeşil çatılar }\end{array}$ \\
\hline
\end{tabular}

Kaynak: Benedict ve McMahon, 2006:7.

Çalışma kapsamında yukarda belirlenen yeşil altyapı bileşenleri (YAB) Coğrafi Bilgi Sistemleri (CBS) araçları kullanılarak tanımlanmıştır. CBS farklı yabancı bilim adamları tarafından değişik şekillerde tanımlanmıştır. CBS; mekânsal ve mekânsal olmayan veriyi depolayan, analiz eden ve görüntüleyen bilgi sistemidir şeklinde tanımlanmıştır (Kaplıhan, 2014:37). Teknolojik açıdan ele alındığında konumsal veriyi toplayan, depolayan, işleyen dönüştüren ve gösteren araçlar bütünüdür şeklinde tanımlanmıştır. CBS'nin bileşenleri; insan, yazılım, donanim ve metottur. 
Şekil 1.2 Yeşil Altyapı Sistemi Bileşenleri

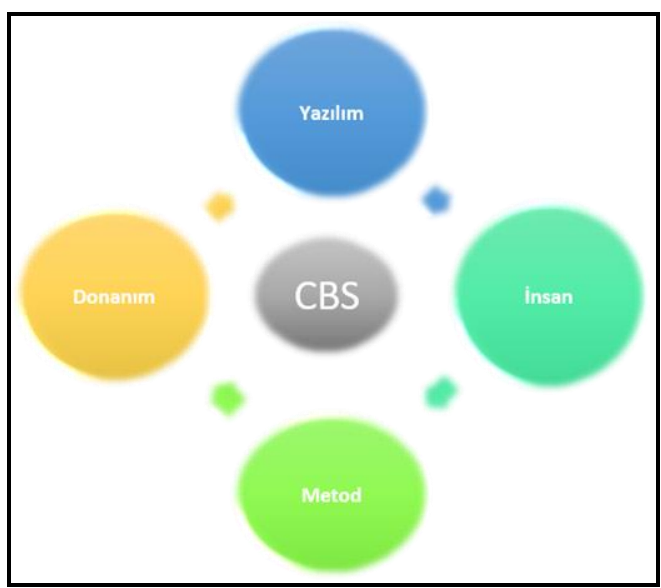

Kaynak: Yazarlar tarafından oluşturulmuştur.

CBS'nin yararlarını sınırlandırmak neredeyse olanaksızdır. Ancak CBS'nin yararları bakımından birkaç örnek verilebilir;

- Bilgi akışını hızlandırır,

- Daha verimli üretim ve belge yönetimi sağlar,

- İş verimliliğini arttırır,

- Etkili ve doğru incelemeler (ivedi duruma karışma, önemli bilgi incelemeleri vb.) sağlar,

- Veri güncelleme kolaylığı sağlar,

- İş gücünü arttırır ve zaman yitimini önler.

CBS’nin kullanıldığı alanlara bakıldığında;

- Çevre Yönetimi

- Doğal Kaynak Yönetimi

- Mülkiyet-İdari Yönetim

- Savunma ve güvenlik

- Sağlık yönetimi

- Bayındırlık hizmetleri

- Eğitim hizmetleri

- Orman yönetimi

- Ticaret ve sanayi gibi alanlarda CBS'den yararlanılmaktadır.

\section{MATERYAL ve YÖNTEM}

\subsection{Materyal}

Araştırma alanı, Doğu Anadolu Bölgesi'nde Yukarı Murat-Van Bölümü'ndeki Van Gölü kapalı havzasında, $42^{\circ} 40^{\prime}$ ve $44^{\circ} 30^{\prime}$ doğu boylamları ile $37^{\circ} 43^{\prime}$ ve $39^{\circ} 26^{\prime}$ kuzey enlemleri arasındaki, Van ilinde yer almaktadır. Çalışmanın temel materyalini Van Kent merkezi ve yakın çevresi oluşturmaktadır.

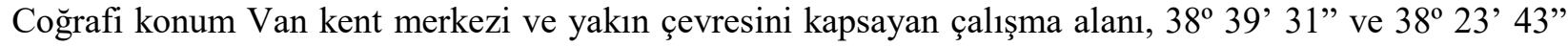
kuzey enlemleri ile $43^{\circ} 27^{\prime} 32^{\prime \prime}$ ve $43^{\circ}$ 19' 7" doğu boylamları arasında yer alan çalışma alanı 30734 ha 
büyüklüğündedir. Çalışma alanını Van Büyükşehir Belediyesi mücavir alan sınırları oluşturmaktadır. Buna göre çalışma alanı, bir alanı kaplamaktadır. Alanın batı kısmında Van Gölü, doğusunda Kıratlı, Kevenli, Bostaniçi, Karpuzalanı ve Bakraçlı yerleşim alanları, güneyinde Bakacık, Kavurma, Kurubaş yerleşim alanları ve kuzeyinde ise Tevekli ve Topraktaş yerleşim alanları bulunmaktadır.

Tablo 2.1 Çalışma Kapsamında Kullanılan Materyaller ve Kaynakları

\begin{tabular}{|c|c|}
\hline Çalışma kapsamaında kullanılan harita ve veriler & Kaynak kişi/kurum \\
\hline - $\quad$ Konu ile ilgili Türkçe ve yabancı kaynaklar & \\
\hline - $\quad$ Arazi fotoğrafları & Orjinal \\
\hline $\begin{array}{ll}\text { - } & \text { Toprak haritası } \\
\text { - } & \text { Bitki örtüsü haritası } \\
\text { - } & \text { Hidrolojik haritası } \\
\text { - } & \text { Topoğrafik yapı haritası } \\
\text { - } & \text { Önemli doğa alanları haritası } \\
\text { - } & \text { Arazi kullanım/arazi örtüsü haritası } \\
\text { - } & \text { Korunan alanlar haritası } \\
\text { - } & \text { Ulaşım ağı haritası }\end{array}$ & $\begin{array}{l}\text { Van Büyükşehir Belediyesi, İmar ve } \\
\text { Şehircilik Müdürlügünden elde } \\
\text { edilen veriler ile haritalar yazarlar } \\
\text { tarafından oluşturulmuştur. }\end{array}$ \\
\hline - $\quad$ Nüfus özellikleri & TUIK, Van Büyükşehir Belediyesi \\
\hline
\end{tabular}

Kaynak: Yazarlar tarafindan oluşturulmuştur. 
Şekil 2.1 Çalışma Alanı Coğrafik Konumu
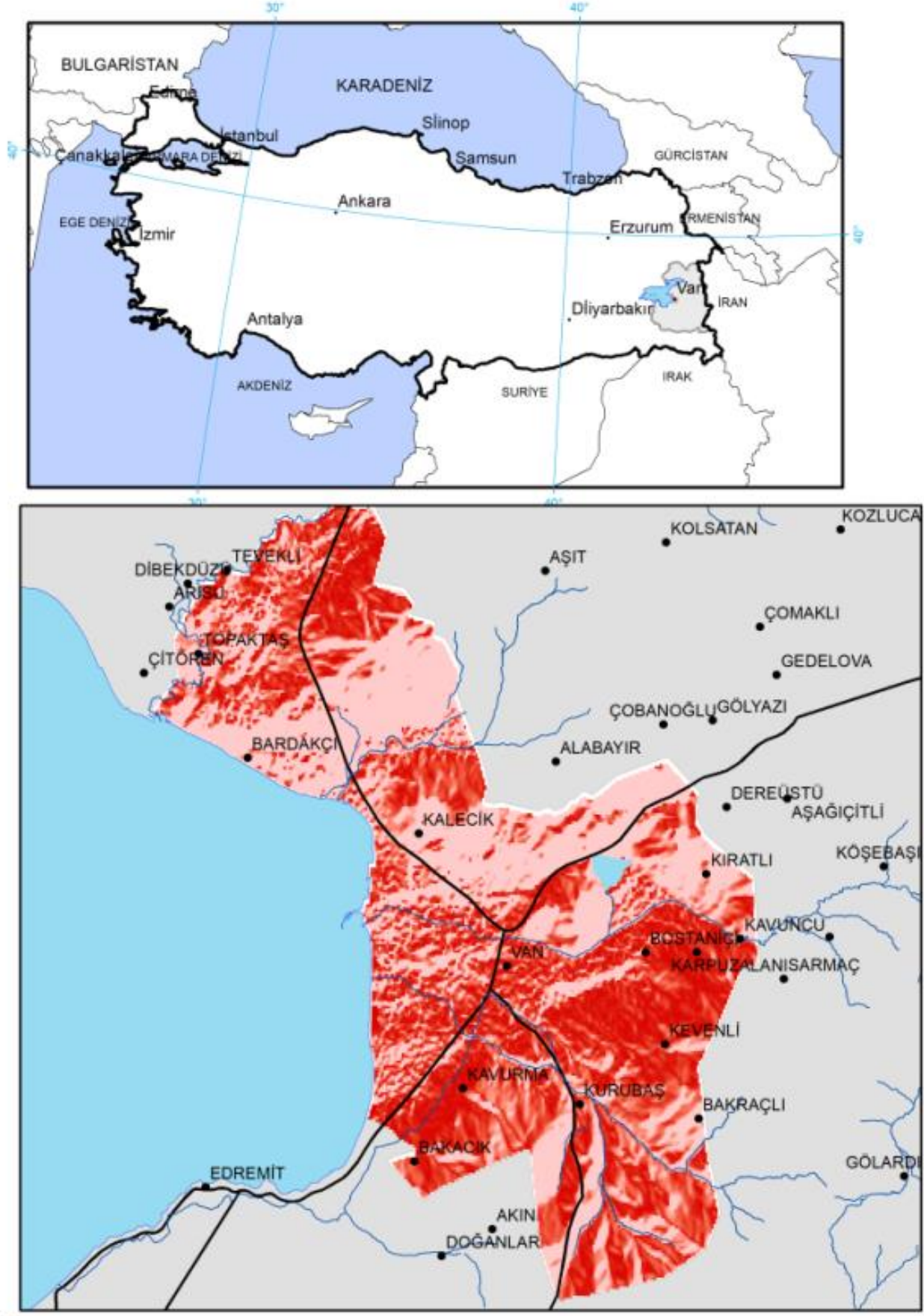

Akarsular

- Yerleşim merkezi

Ana Yollar

Göller

Van Ilii

Çalışma Alanı

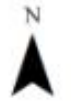

$200 \quad 300$

400

Kaynak: Yazarlar tarafından oluşturulmuştur. 
Şekil 2.2 Çalışma Alanı Toprak Yapısı

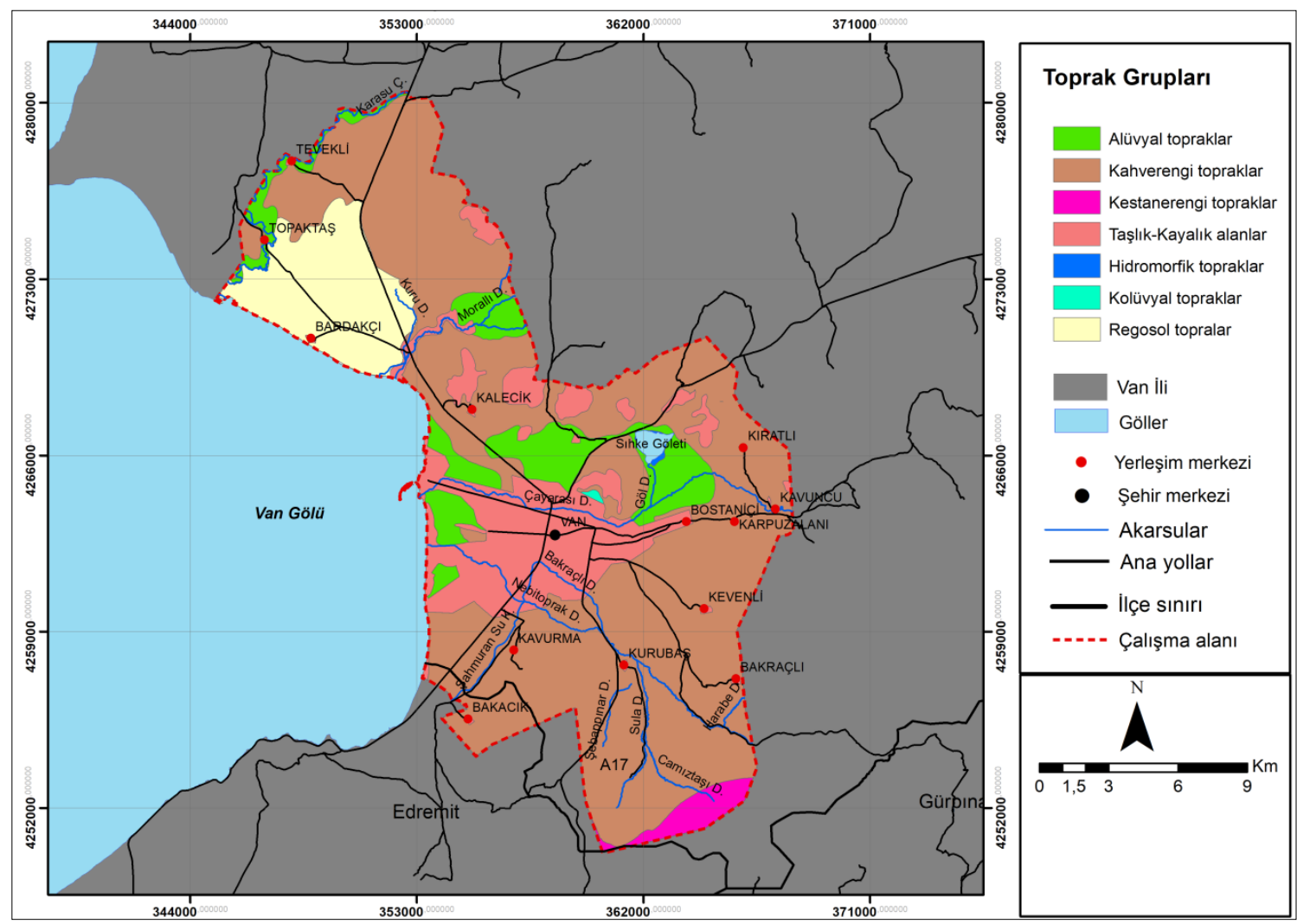

Kaynak: Van Büyükşehir Belediyesi, 2016 
Şekil 2.3 Çalışma Alanı Bitki Örtüsü

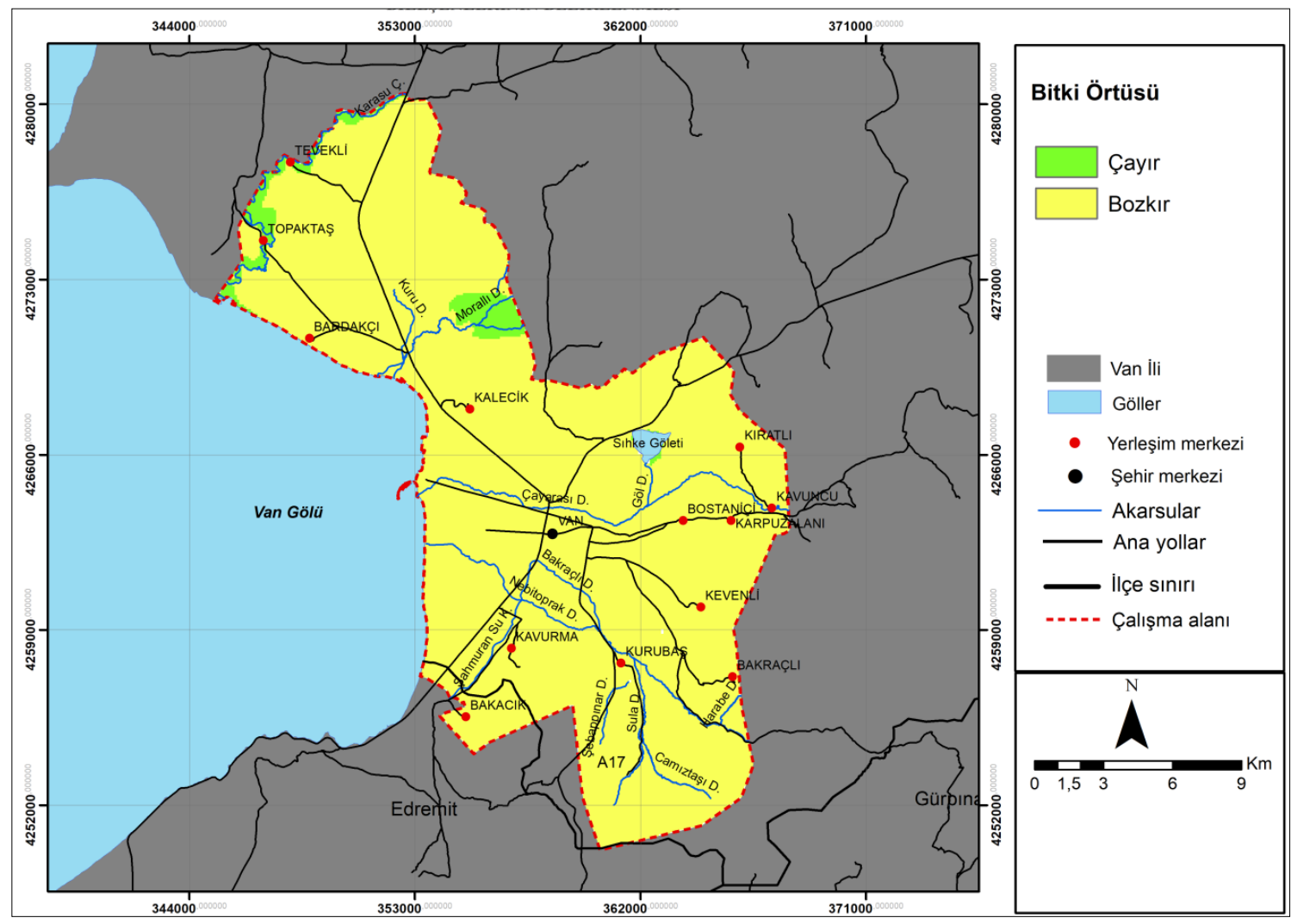

Kaynak: Van Büyükşehir Belediyesi, 2016 
Şekil 2.4 Çalışma Alanındaki Hidrolojik Öğeler

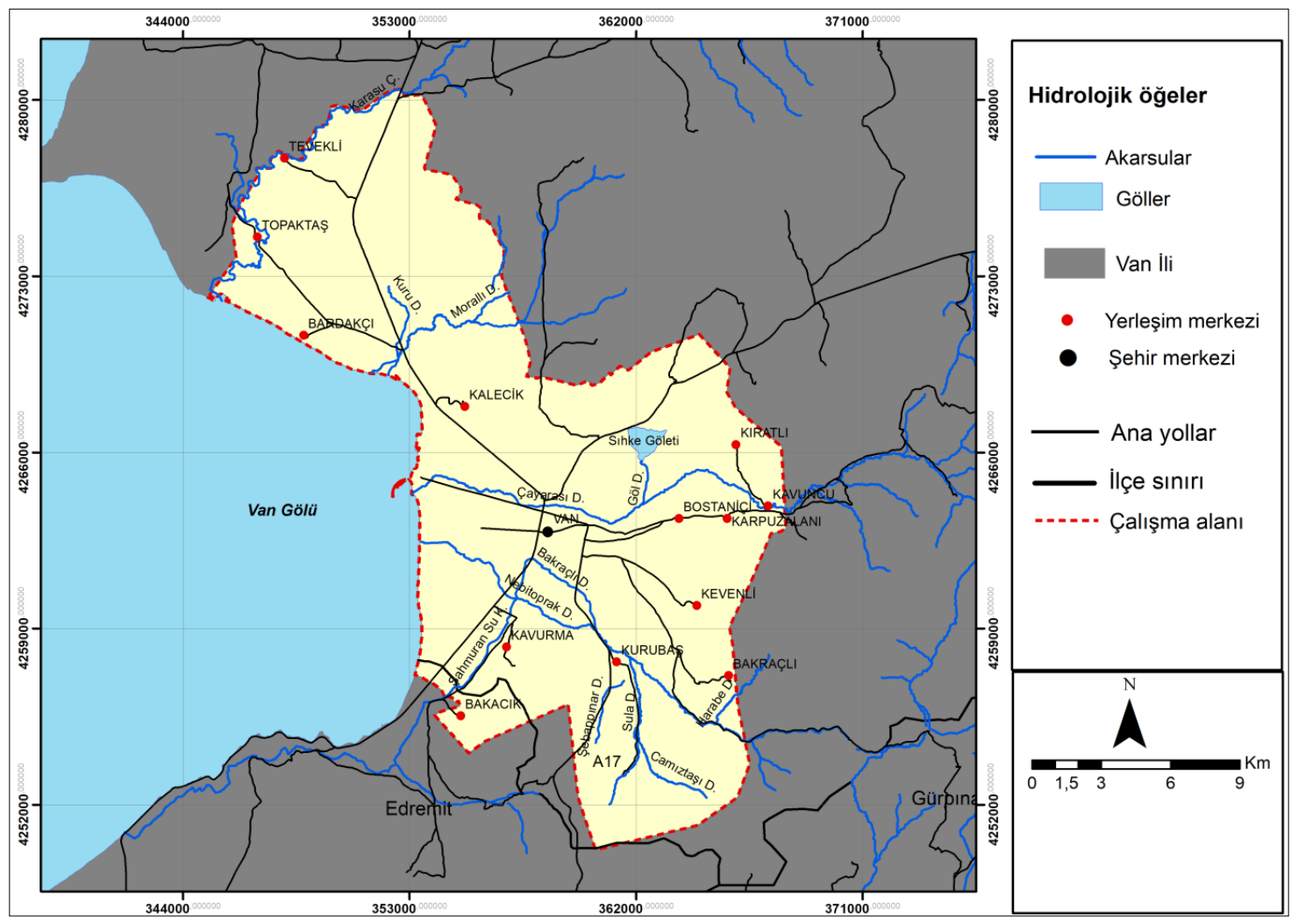

Kaynak: Van Büyükşehir Belediyesi, 2016 
Şekil 2.5 Çalışma Alanının Yükseklik Grupları

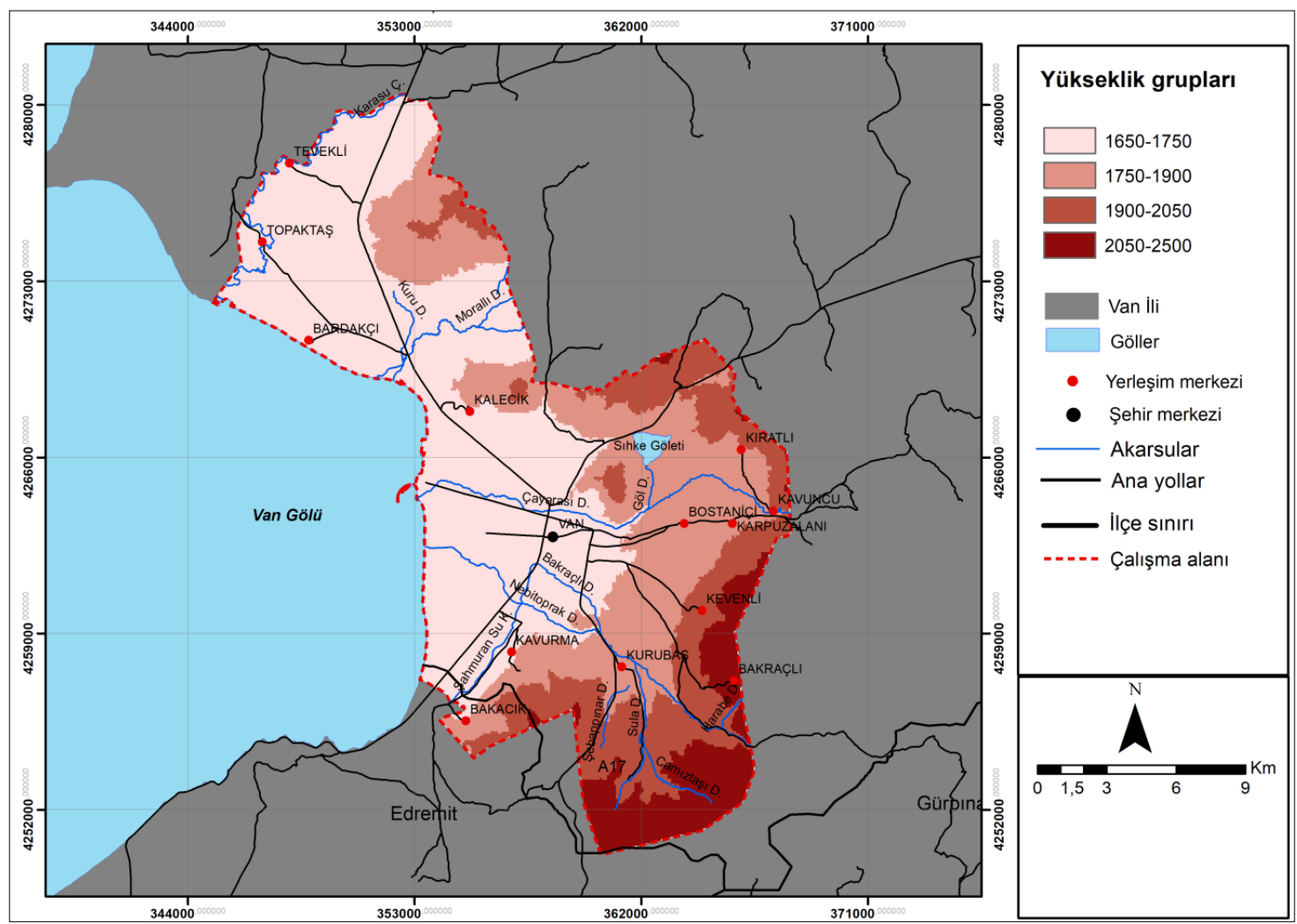

Van Kaynak: Van Büyükşehir Belediyesi, 2016 
Şekil 2.6 Çalışma Alanının Eğim Durumu

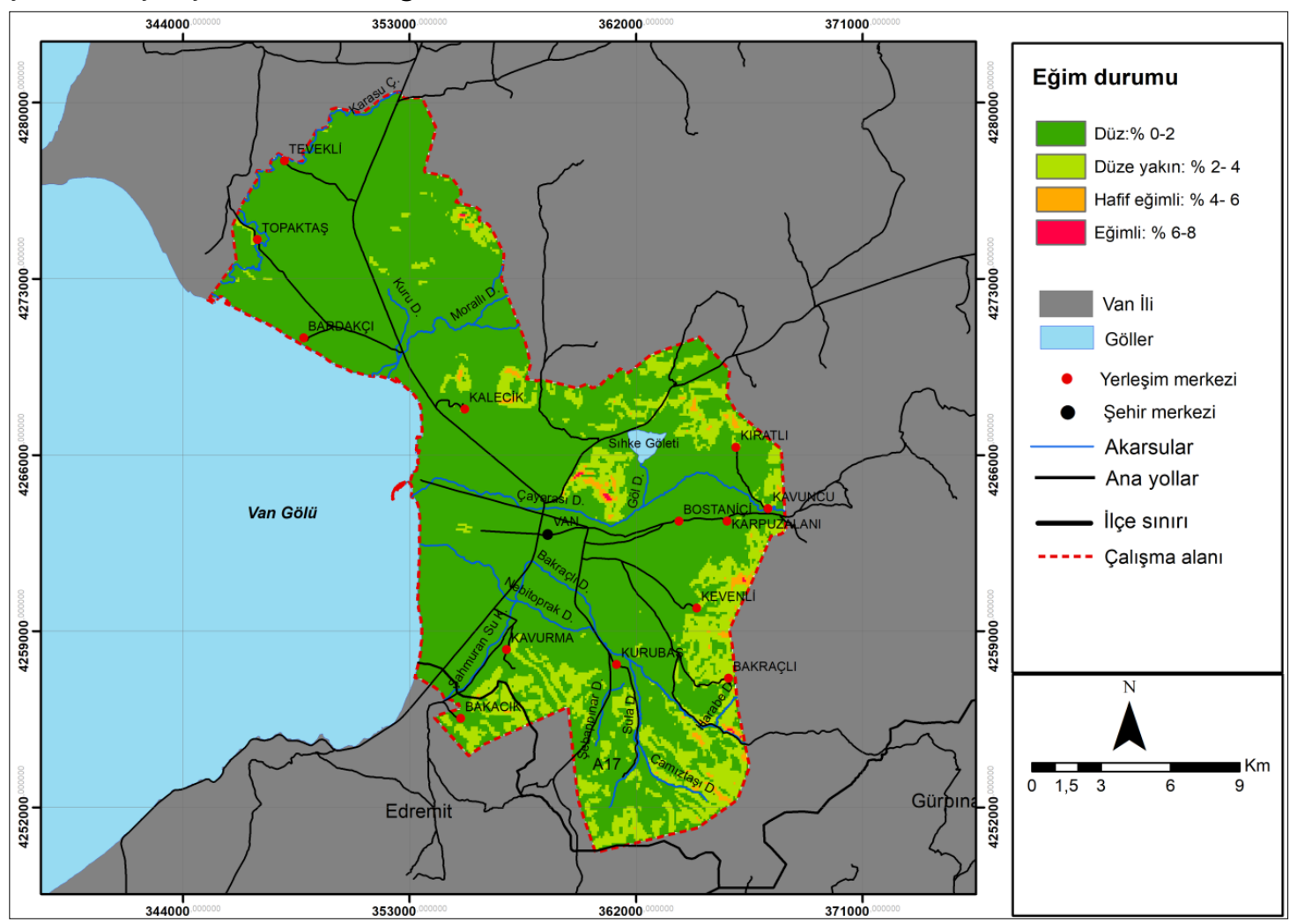

Kaynak: Van Büyükşehir Belediyesi, 2016 
Şekil 2.7 Çalışma Alanındaki Önemli Doğa Alanları Sınırı Ve Habitatlar

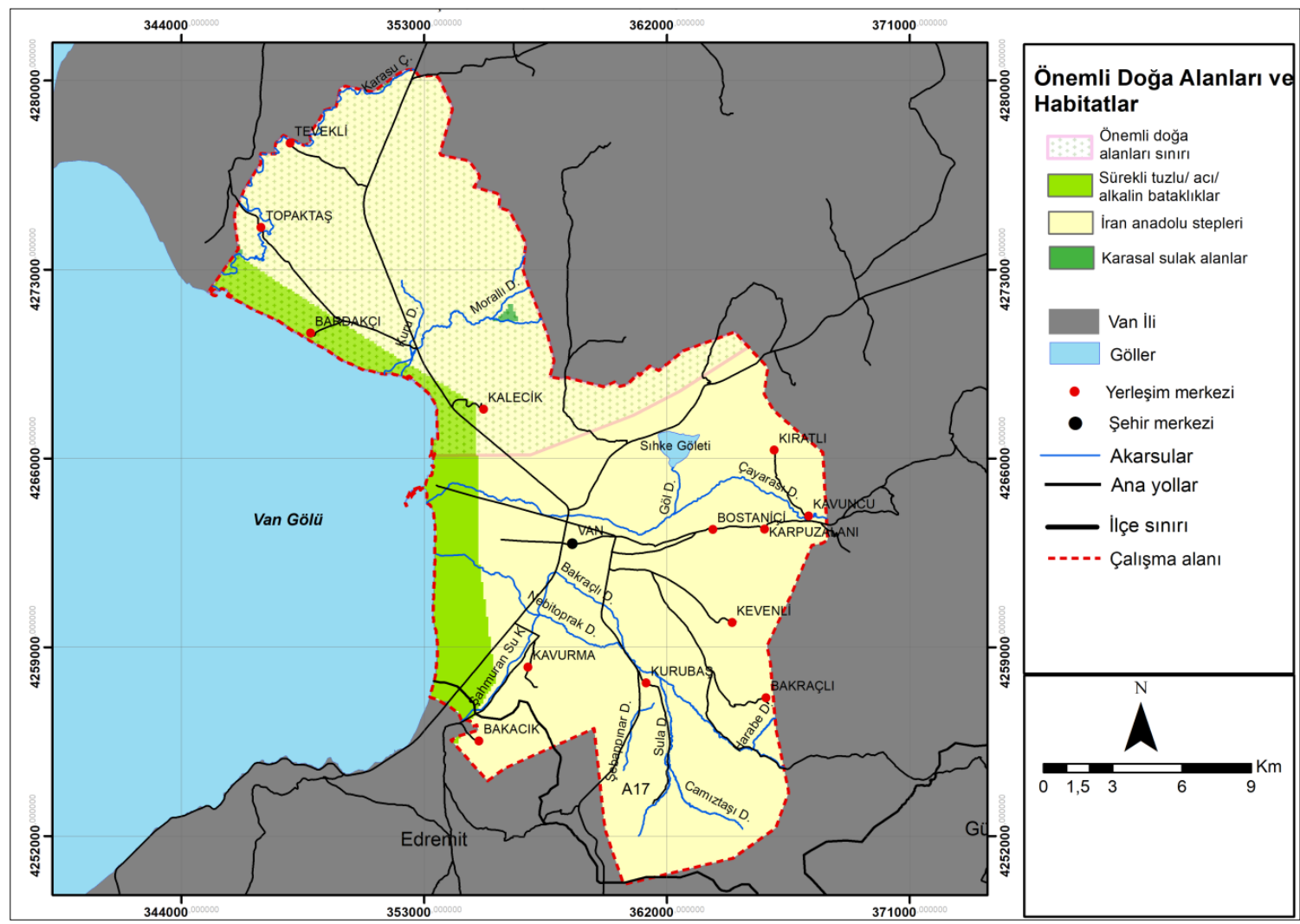

Kaynak: Van Büyükşehir Belediyesi, 2016 
Şekil 2.8 Çalışma Alanı Şimdiki Alan Kullanımları

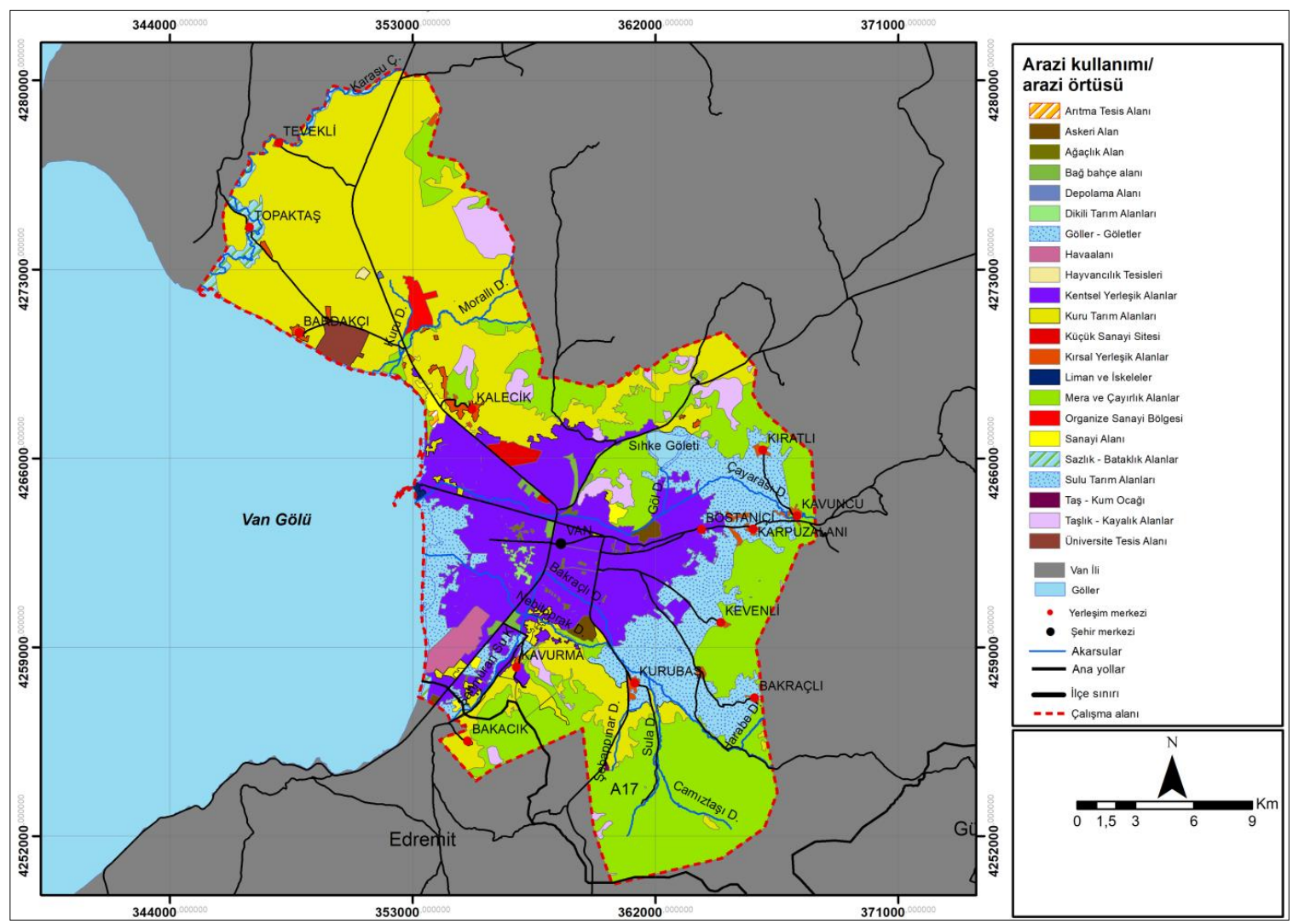

Kaynak: Van Büyükşehir Belediyesi, 2016. 
Şekil 2.9 Çalışma Alanı Korunan Alanlar

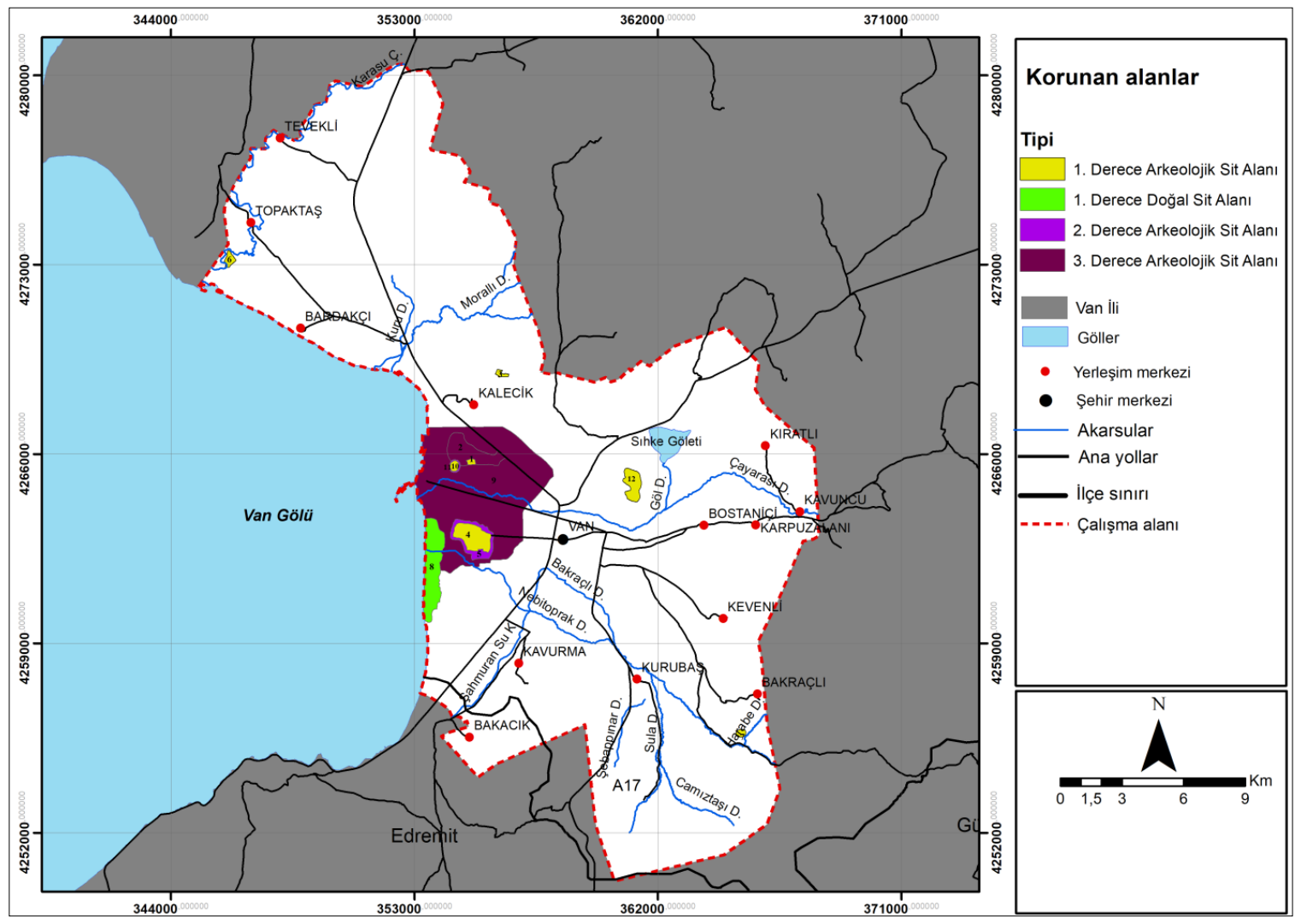

Kaynak: Van Büyükşehir Belediyesi, 2016 
Şekil 2.10 Çalışma Alanı Ulaşım Ağı

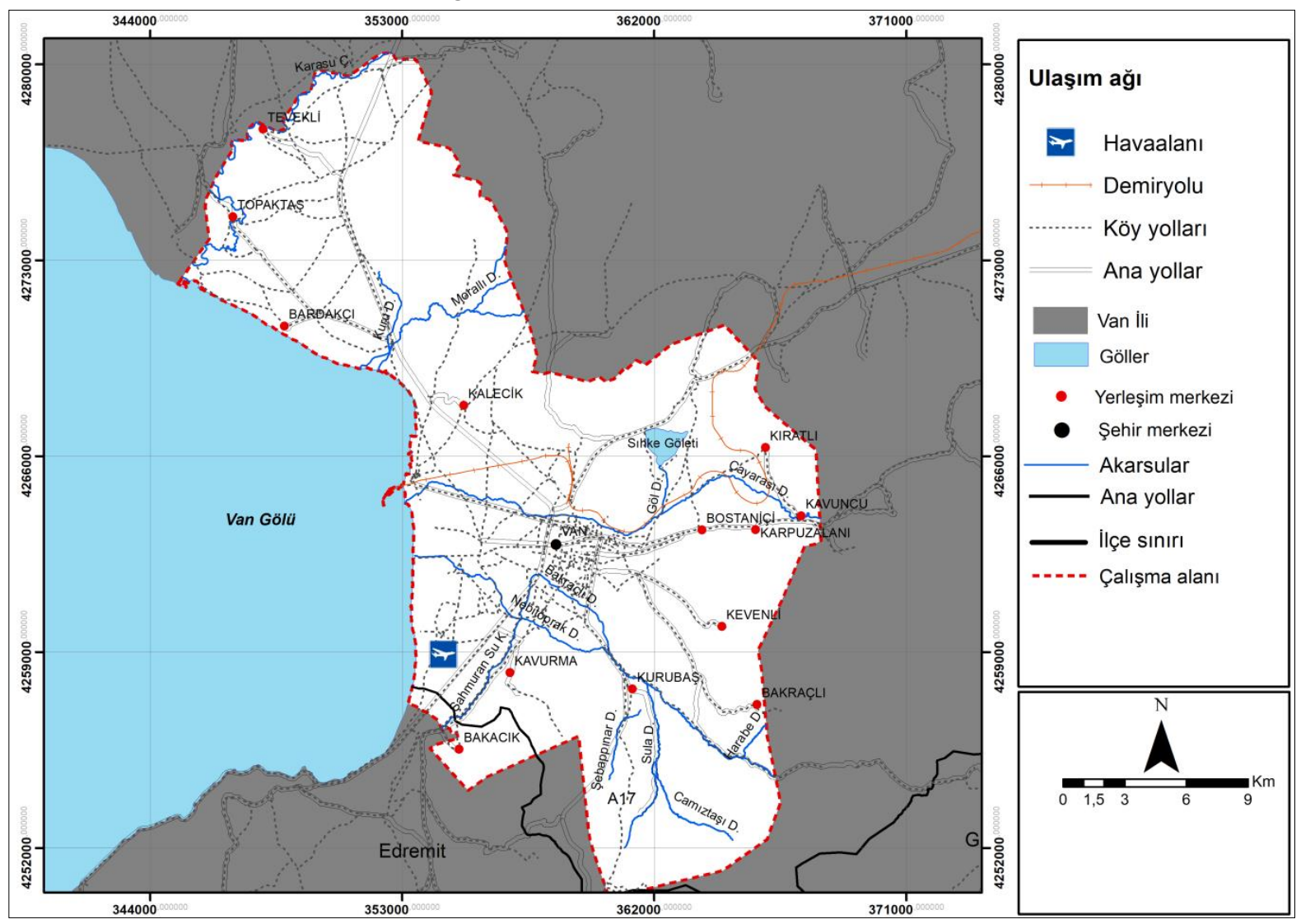

Kaynak: Van Büyükşehir Belediyesi, 2016.

Çalışma alanı olarak belirlenen Van Kent merkezi ve yakın çevresi, kendine özgü, ender rastlanan jeolojik, jeomorfolojik, dağ, göl ve akarsu gibi farklı ekosistemlerin birlikteliğine ve içinde bulunduğu İran-Turan fitocoğrafya bölgesinin özelliklerine bağlı olarak biyoçeşitlilik ve peyzaj çeşitliliği bakımından hem ulusal hem de uluslararası düzeyde önemli bir alandır. Van Gölü, Van ilindeki ve kıyısındaki diğer illerin biyoçeşitliliğini, ekosistem işlev ve hizmetlerini etkileyen en önemli doğal peyzaj öğelerinden biridir. Çalışmanın amacı; doğal ve kültürel peyzajlar bakımından zengin olan Van Kent'i öncesinde böyle bir çalışma konusu olmaması sebebi ile bu konu ile ilgili sonradan yapılacak çalışmalara referans olması ve Van Kenti'nin neredeyse el değmemiş doğal peyzajları ve kültürel peyzajlarının YAB bileşenleri olarak işlevlerinin ortaya konmasıdır. Bu bağlamda, Van Kent merkezi ve yakın çevresinde doğal ve kültürel peyzaj öğeleri bakımından CBS araçları ile ARCGIS 10.2 ortamında analiz edilerek YAB bakımından Van Kent merkezi çevresinde uygunluk analizi yapılmış ve sonrasında YAB olarak; çekirdek, alan ve koridorlar belirlenmiştir.

\subsection{Yöntem}

Çalışmanın yöntemi, Van kent merkezi ve yakın çevresinin yeşil altyapı bileşenlerinin belirlenmesi bağlamında; Doğal ve kültürel parametrelerin belirlenmesi, doğal ve kültürel parametrelerin CBS araçları kullanılarak analiz edilmesinden oluşmaktadır. Yöntemin aşamaları aşağıdaki şekilde verilmiştir (Şekil 4.1).

Yöntemin geliş̧irilmesinde; Using expert knowledge in combining green infrastructure and ecosystem services in landuse planning: an insight into a new placebased methodology (Kopperoinen ve ark., 2014:13671369), Doğa Korumada Sürdürülebilir Bir Yaklaşım, Ekolojik Ağların Belirlenmesi ve Planlanması: Çeşme 
Urla Yarımadası Örneği (Coşkun Hepcan, 2008:70-84), Regional Landscape Analysis and Reserve Design to Conserve Florida's Biodiversity (Hoctor, 2003:65-88) ve kaynaklarından yararlanılmıştır.

\section{Yöntemin aşamaları;}

- Doğal ve kültürel parametrelerin; belirlenmesi,

- Doğal ve kültürel parametrelerin CBS araçları kullanılarak analiz edilmesi,

- Vektör verilerin Raster veriye dönüştürülmesi-Conversion Tools- To Raster- Polygon to Raster aracı kullanılarak.

- Yoğunluk analizleri-Yol yoğunluğu-Nüfus yoğunluğu- Spatial Analyst Tools- Density aracı kullanılarak.

- Raster verilerin yeniden sinıflandırılması- 3D Analyst Tools- Raster reclass- Reclassify aracı kullanılarak.

- Sınıflandırılan verilerin ağırlıklandırılarak çakıştırılması-Spatial Analyst Tools- Map algebra-Raster Calculator aracı kullanılarak yapılmıştır.

\subsubsection{Doğal ve Kültürel Parametrelerin Belirlenmesi}

Yeşil altyapı bileşenleri, küçük ölçekli bir mahalle parkından büyük doğa koruma alanına kadar farklı büyüklüklerdeki doğal ve kültürel alanları kapsamaktadır. Bu kapsamda araştırmada YAB'ni belirlemek için; toprak yapısı, bitki örtüsü, hidrolojik öğeler, önemli doğa alanları ve habitatlar, eğim sınıfları, arazi kullanımı/arazi örtüsü, korunan alanlar, ulaşım ağı ve nüfus yoğunluğu olmak üzere 9 adet parametre belirlenmiştir.

Tablo 2. 2 Ekolojik Ve Kültürel Parametreler

\begin{tabular}{|l|l|}
\hline Doğal parametreler & Kültürel parametreler \\
\hline Toprak yapısı & Arazi kullanımı/ arazi örtüsü \\
Bitki örtüsü & Korunan alanlar \\
Önemli doğa alanları ve habitatlar & Ulaşım ağı \\
Hidrolojik öğeler & Nüfus yoğunluğu \\
Topoğrafya; eğim sınıflar & \\
\hline
\end{tabular}

Kaynak: Yazarlar tarafindan oluşturulmuştur.

\subsubsection{Doğal ve Kültürel Parametrelerin CBS Araçları ile Analiz Edilmesi}

- Sayısal verilerin Rastera dönüştürülmesi

Öncelikle analiz aşamalarında kullanılacak ekolojik ve kültürel parametreler belirlenmiş olup belirlenen parametreler ARCGIS 10.2'de Spatial Analyst Tools yardımı ile raster formata dönüştürülmüştür. Analizlere katılacak olan tüm veri katmanları 100 metreye $(100 \mathrm{~m} \mathrm{x} 100 \mathrm{~m})$ örneklenmiştir. Yani, analizler $10000 \mathrm{~m}^{2}$ boyutlarındaki gridlere örneklenen raster veri katmanları temelinde yapılmıştır. Toprak yapısı, bitki örtüsü, hidrolojik öğeler, eğim sınıfları, önemli doğa alanları ve habitatlar, arazi kullanım/arazi örtüsü, korunan alanlar, nüfus ve ulaşım ağına ait ait veriler ARCGIS 10.2 Conversion Tools- To Raster- Polygon to Raster aracı kullanılarak raster veriye dönüştürülmüştür (Şekil 2.11).

- Yoğunluk analizi

- Yol yoğunluğu 
Ulaşım ağı belirlenirken köy yolları, kara yolları, demir yolları kullanılarak bir yol haritası ortaya çıkarılmıştır. Köy yolları çoğunlukla şehiriçi yollar (mahalle ve köy yolları) ve köy yollarından oluşmakta ve asfalt veya stabilize yollar olup tek şeritli yollardan oluşmaktadır. Karayolları (ana yollar)asfalt kaplı ve çift şeritli yollardan oluşmaktadır. Yol verileri ARCGIS10.2 ortamında Spatial Analyst Tools- Density- Line Density aracı kullanılarak yol yoğunluk verisi üretilmiştir (Şekil 2.12).

Şekil 2.11 Vektör Verinin Raster Veriye Dönüştürülmesi

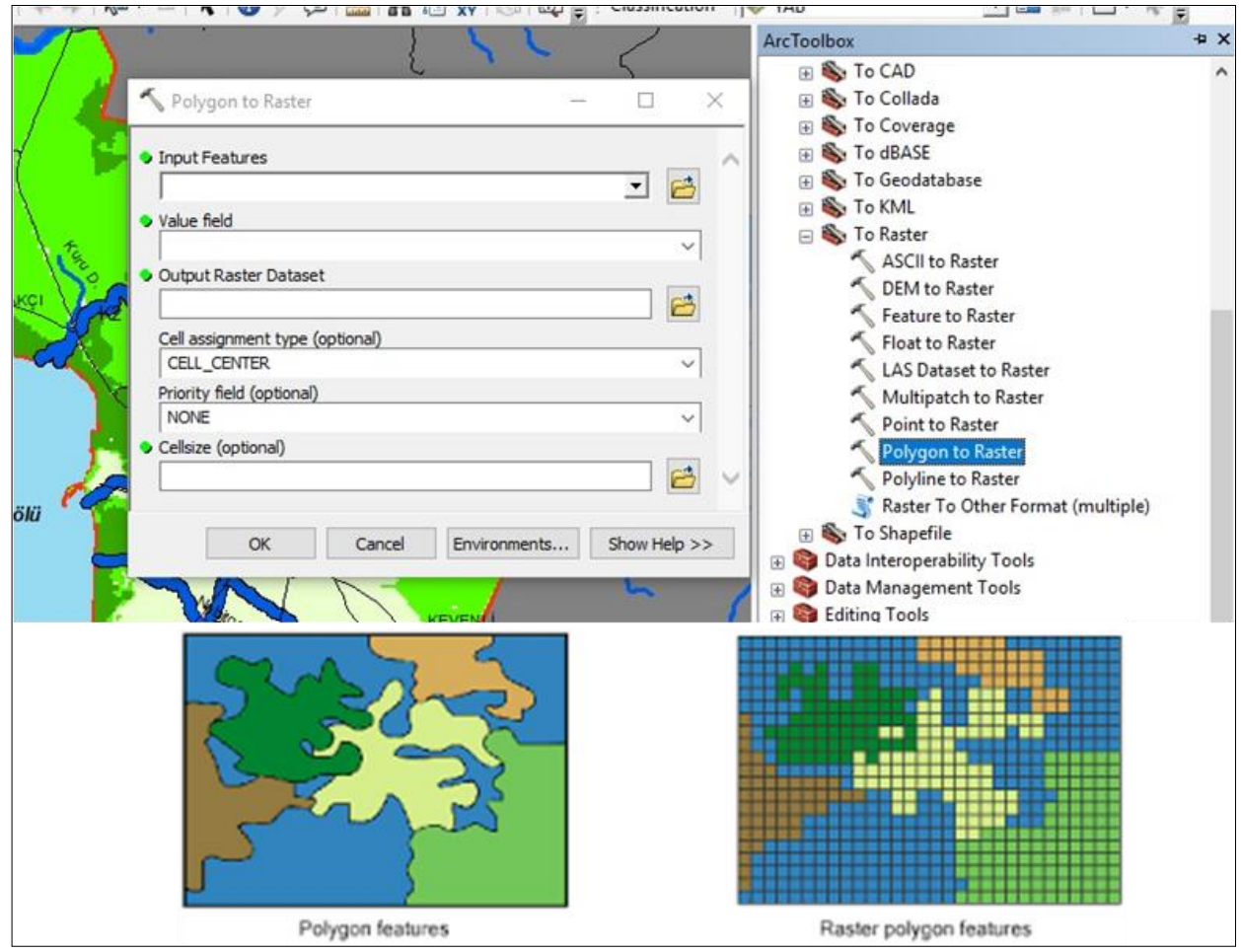

Kaynak: Yazarlar tarafindan oluşturulmuştur.

- Nüfus yoğunluğu

Araştırma alanındaki yerleşim yerlerine ait nüfus verileri kullanılarak ARCGIS 10.2 Spatial Analyst modülü ile nüfus yoğunluğu haritası üretilmiştir. Van ili dışarıya sürekli göç veren bir kent olmasına rağmen nüfus miktarı sürekli artış göstermektedir. İl dışına göç en çok, 2011 yılında yaşanan deprem sebebi ile olmuştur. 2016 yılı Van nüfusu 1100000 kişidir. Kent merkezi ve merkez ilçelerde nüfus yoğunluğu fazla olup kırsal yerleşimlere doğru gidildikçe nüfus yoğunluğu azalmaktadır. Çalışma alanı sınırları için giren Van kent merkezi ve yakın çevresi nüfusu; Van 43359, Bostaniçi 28612, Karpuz alanı 3480, Bakraçlı 1094, Kavuncu 2015, Kıratl1 1219, Bakacık 137, Kevenli753, Bardakçı 2162, Kalecik 2309, Kavurma 110, Kurubaş 1942, Tevekli 390 ve Topraktaş 457'dir ( TUIK, 2016). Nüfus verileri ARCGIS 10.2 ortamında Spatial Analyst Tools- Density- Point Density aracı kullanılarak Nüfus yoğunluğu verisi üretilmiştir (Şekil 2.3). 


\subsubsection{Doğal ve Kültürel Parametrelerin Yeniden Sinıflandırılması}

Yeşil altyap1 bileşenlerinin belirlenmesi amacıyla kullanılan parametrelere ait verilerin ortak bir değerlendirme birimine getirilmesi amacıyla veriler konuyla ilgili önceki araştırmalardan (örn: Coşkun Hepcan, 2008; Hector, 2003; Miller ve ark., 2003), yararlanılarak 1-3 aralığında yeniden sınıflandırılmıştır. Sınıflandırma aşamasında doğal ve kültürel parametreler ARCGIS 10.2'de 3D Analyst Tools- Raster reclassReclassify aracı kullanılmıştır (Şekil 2.4). Buna göre;

1: YAB bakımından çok uygun olan alanları,

2: YAB bakımından uygun alanları,

3: YAB bakımından uygun olmayan alanları/uygun değili ifade etmektedir (Tablo 2.2)

Tablo 2.3 Uygunluk Tanımı ve Puanı

\begin{tabular}{|l|l|l|}
\hline Uygunluk düzeyi & Tanım & $\begin{array}{l}\text { Puan } \\
\text { (İndeks/önem } \\
\text { ) }\end{array}$ \\
\hline Çok uygun alanlar & YAB bakımından çok yüksek potansiyele sahip alanlar & $\mathbf{1}$ \\
\hline Uygun alanlar & YAB bakımından yüksek potansiyele sahip alanlar & $\mathbf{2}$ \\
\hline Az uygun alanlar/uygun değil & YAB bakımından düşük potansiyele sahip alanlar & $\mathbf{3}$ \\
\hline \multicolumn{2}{|r}{ Kaynak: Yazarlar tarafından oluşturulmuştur } \\
\hline
\end{tabular}

Şekil 2.12 Yoğunluk Analizi

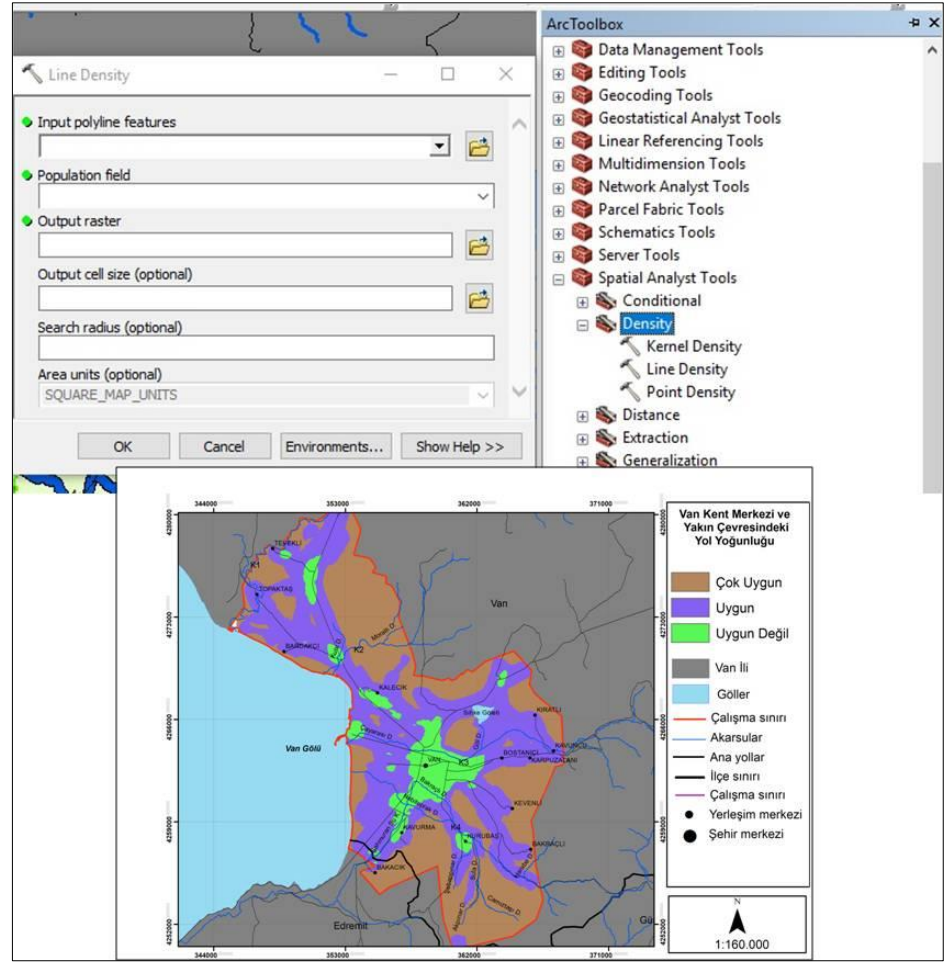

Kaynak: Yazarlar tarafından oluşturulmuştur. 
Çalışma alanındaki parametreler ve parametrelerin alt grupları yeniden sınıflandırılarak YAB bakımından uygunluk potansiyellerine göre puan verilmiştir (Tablo 2.4).

Şekil 2.13 Parametrelerin Sınıflandırılması (Reclassify)

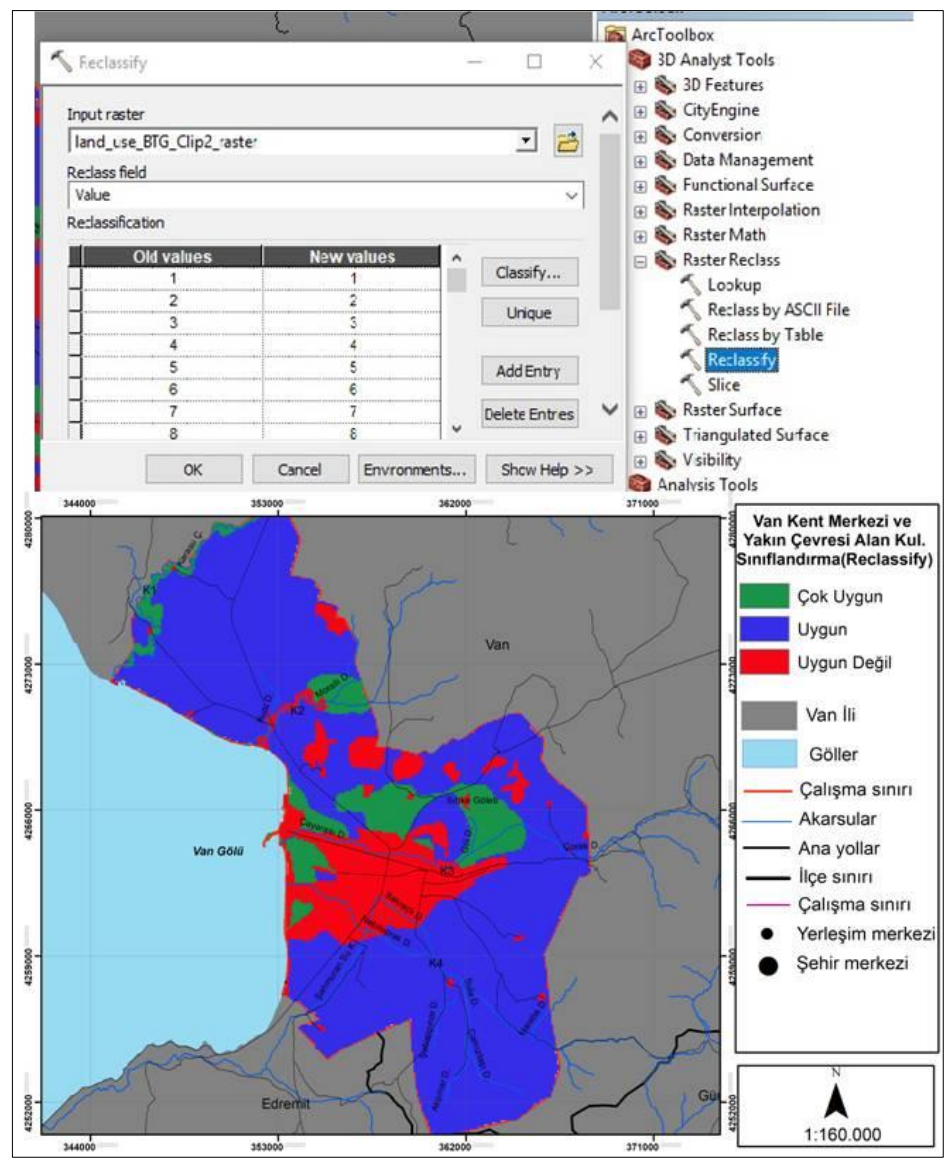

Kaynak: Yazarlar tarafından oluşturulmuştur. 
Tablo 2.4 Doğal ve Kültürel Parametrelerin Sınıflandırılmas1/

\begin{tabular}{|c|c|c|c|}
\hline $\begin{array}{l}\text { Doğal ve Külttürel } \\
\text { Parametreler }\end{array}$ & $\begin{array}{l}\text { Puan } \\
\text { (Önem) }\end{array}$ & $\begin{array}{l}\text { Doğal ve Kültürel } \\
\text { Parametreler }\end{array}$ & $\begin{array}{l}\text { Puan } \\
\text { (Önem) }\end{array}$ \\
\hline Toprak yapısı & & Bitki örtüsü & \\
\hline Alüvyal topraklar & 1 & Bozkır & 3 \\
\hline Kolüvyal topraklar & 1 & Mera & 2 \\
\hline Hidromorfik topraklar & 1 & Çayır & 1 \\
\hline Kestane rengi topraklar & 2 & Hidrolojik Öğeler & \\
\hline Kahverengi topraklar & 2 & Akarsular $>5 \mathrm{~km}$ & 1 \\
\hline Regosol topraklar & 2 & Akarsular $<5 \mathrm{~km}$ & 2 \\
\hline Taşlık-kayalık alanlar & 3 & Göller & 1 \\
\hline $\begin{array}{l}\text { Topoğrafya } \\
\text { Eğim sınıfları } \\
\end{array}$ & & Önemli doğa alanları ve habitatlar & \\
\hline Düz $\% 0-2$ & 1 & Önemli doğa alanları sınırı & 1 \\
\hline Hafif eğimli \% 2-4 & 1 & Sürekli tuzlu/acı/ alkalin bataklıklar & 1 \\
\hline Orta eğimli \% 4-6 & 2 & İran Anadolu stepleri & 3 \\
\hline Eğimli \% 6-8 & 3 & Karasal bataklıklar & 2 \\
\hline Arazi kullanımı/arazi örtüsü & & Korunan alanlar & \\
\hline Çayır- mera & 1 & Dereceden Arkeolojik Sit Alanı & 1 \\
\hline Bağ- bahçe alanları & 1 & Dereceden Arkeolojik Sit Alanı & 1 \\
\hline Ağaçlık alanlar & 1 & Dereceden Arkeolojik Sit Alanı & 1 \\
\hline Göller & 1 & Dereceden Doğal Sit Alanı & 1 \\
\hline Sazlık-bataklık alanlar & 1 & Diğer alanlar & 3 \\
\hline Kuru tarım alanları & 1 & Nüfus yoğunluğu & \\
\hline Kırsal yerleşik alanlar & 2 & Nüfus sayıs1 $<10000$ & 1 \\
\hline Kentsel yerleşik alanlar & 3 & Nüfus sayıs1 10000- 20000 & 2 \\
\hline Taşlık-kayalık alanlar & 3 & Nüfus sayısı $>20000$ & 3 \\
\hline Depolama alanları & 3 & Yol yoğunluğu & \\
\hline Sanayi alanları & 3 & $0-15 \mathrm{~m}$ & 1 \\
\hline Havaalanı & 3 & $15-30 \mathrm{~m}$ & 2 \\
\hline Taş-kum ocağı & 3 & $30-45 \mathrm{~m}$ & 3 \\
\hline Askeri alanlar & 3 & $45-60 \mathrm{~m}$ & 3 \\
\hline
\end{tabular}

Kaynak: Yazarlar tarafindan oluşturulmuştur. 


\subsubsection{Parametrelerin Çakıştırılması (Ăgırlıklandırma Analizi)}

Yeşil altyapı bileşenlerinin belirlenmesi amacıyla yeniden sınıflandırılan ekolojik ve kültürel parametrelere önem derecelerine göre toplamda 1 olacak şekilde ağırlık puanı verilmiştir (Tablo 2.4) Ağırlık puanıyla çarpılan haritalar çakıştırılarak; yeşil altyapı bileşenleri bakımından çok uygun, uygun ve uygun olmayan alanlar belirlenmiştir. Çakıştırma aşaması ARCGIS 10.2'de Spatial Analyst Tools- Map algebra-Raster Calculator aracı kullanılmıştır (Şekil 2.5).

Tablo 2.5 Doğal ve Kültürel Parametrelerin Ağırlık Puanı

\begin{tabular}{|l|l|}
\hline Ekolojik ve Kültürel parametreler & Ăğılık puanı (Önem derecesi) \\
\hline Toprak yapısı & $\mathbf{0 . 1}$ \\
\hline Bitki örtüsü & $\mathbf{0 . 1}$ \\
\hline Önemli doğa alanları ve habitatlar & $\mathbf{0 . 2}$ \\
\hline Hidrolojik öğeler & $\mathbf{0 . 2}$ \\
\hline Eğim sınıfları & $\mathbf{0 . 0 5}$ \\
\hline Arazi kullanımı/örtüsü & $\mathbf{0 . 1 5}$ \\
\hline Korunan alanlar & $\mathbf{0 . 1}$ \\
\hline Ulaşım ağı & $\mathbf{0 . 0 5}$ \\
\hline Nüfus yoğunluğu & $\mathbf{0 . 0 5}$ \\
\hline
\end{tabular}

Kaynak: Yazarlar tarafından oluşturulmuştur. 
Şekil 2.14 Parametrelerin Ağırlıklandırılarak Çakıştırılması

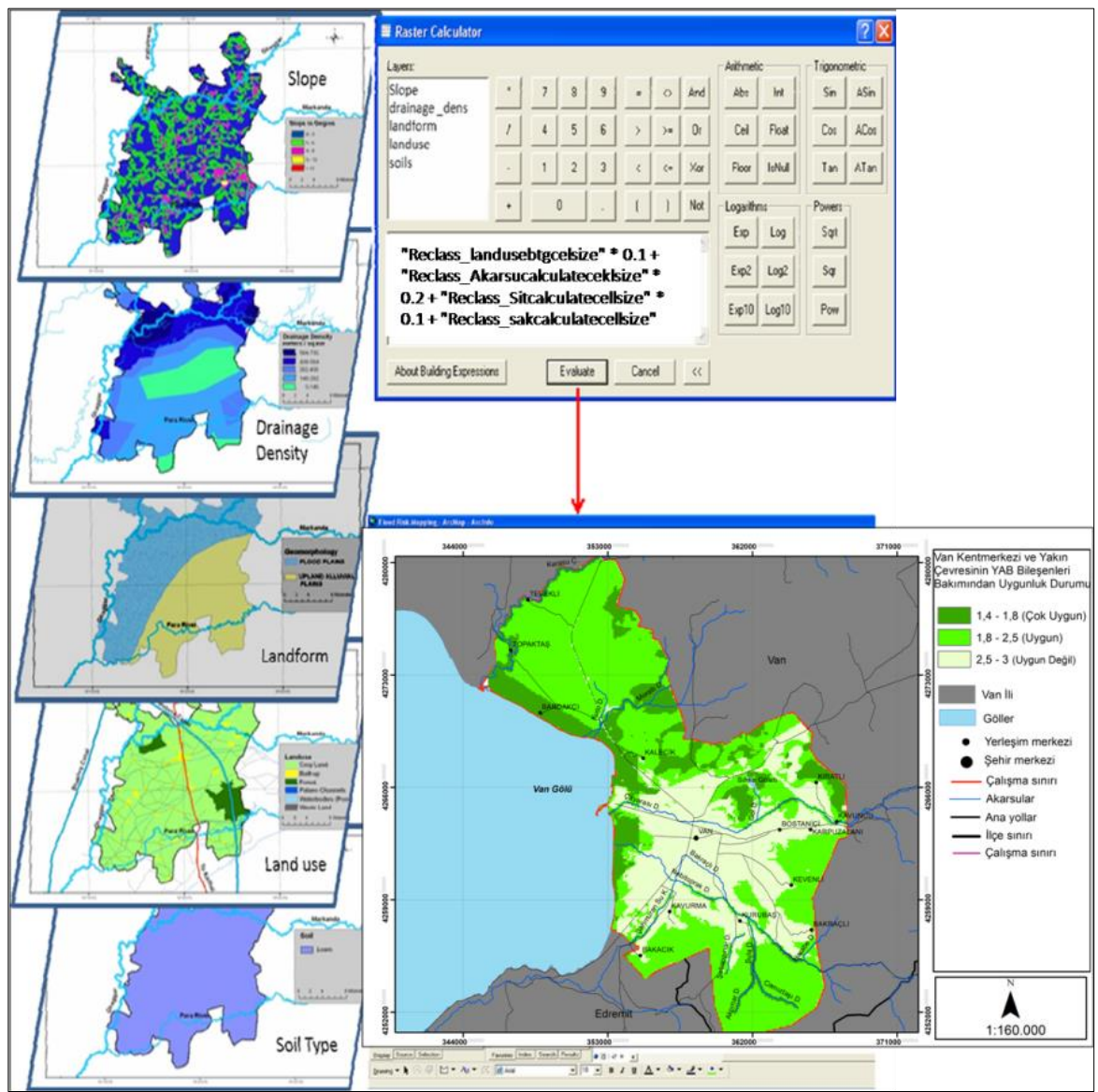

Kaynak: Yazarlar tarafindan oluşturulmuştur.

\subsection{Bulgular}

CBS araçları kullanılarak yapılan analizler sonucu Van Kent Merkezi ve yakın çevresinin YAB bakımından uygunluk durumu belirlenmiştir. Buna göre yapılan ağırlıklandırma analizi sonucunda uygunluk değeri bakımından minimum değer: 1,6 ve maksimum değer: 3 olarak belirlenmiştir. Yapılan analizler sonucunda çalışma alanında YAB bakımından uygunluk düzeyi, 1,4 ve 3 arasında değerler almıştır (Şekil 2.6). Buna göre çalışma alanında;

1,4 ve 1,8 arasında değer alan yerler: YAB bakımından çok uygun ve çekirdek alan (Şekil 2.7).

1,8 ve 2,5 arasında değer alan yerler: YAB bakımından uygun ve alan (Şekil 2.8).

2,5 ve 3 arasında değer alan yerler: YAB bakımında uygun değil (az uygun) olarak belirlenmiştir. Çalışma alanındaki uzunluğu 5 m'den fazla olan ve sürekli olan akarsular ve yakın çevreleri koridor (Şekil 2.9) olarak belirlenmiştir. Koridorların yakın çevreleri 200 m'lik bir zondan oluşmaktadır. Böylece koridor olarak belirlenen akarsular 200 m'lik yakın çevreleriyle beraber alınmıştır. Koridorların 200 m'lik yakın çevrelerindeki zon 3621 sayılı kıyı kanunu baz alınarak belirlenmiştir. Böylelikle çalışma alanında YAB olarak, 10 çekirdek alan (Ç), 16 alan (A) ve 4 koridor (K) belirlenmiştir. Çalışma alanında toplamda 4517 ha çekirdek alan, 16899 ha alanlardan ve geriye kalan da kentsel ve kırsal yerleşmeler ve doğal akarsu koridorlarından oluşmaktadır. Buna göre çalışma alanının \% 14.69'u çekirdek alanlardan ve \% 54.98'de alanlardan 
oluşmaktadır. Yani yaklaşık olarak alanın \%70'i çekirdek ve alanlardan oluşmaktadır. Bu kapsamda YAB bakımından zengin bir durumda olan Van Kent'i ve yakın çevresi için oldukça önemlidir.

Van Kent merkezi ve yakın çevresinde CBS araçları kullanılarak belirlenen YAB olan çekirdek alanlar diğer bileşenler olan alan ve doğal akarsu koridorlarına kıyasla biyolojik çeşitlilik bakımından daha zengindir. Çünkü çekirdeklerin büyük çoğunluğu; sazlık-bataklık alanları ve yakın çevrelerini, hidromorfik topraklar ve alüvyal toprakları, açık yeşil alanları, bağ-bahçe alanlarını, sulu tarım alanlarını ve korunan alanları (1. Derece ASA, 2. Derece ASA ve 3. Derece ASA) içermektedir. Çekirdek alanların büyük çoğunluğu çalışma alanının batısında Van Gölü kıyısında yer almaktadır. Göl kıyısında yer alan sazlık-bataklık alanlar sebebi ile çekirdek alanların büyük kısmı burada bulunmaktadır. Genel olarak birbirine göl kıyısı boyunca devam eden çekirdek alanlar, yerleşim alanları, göl kıyısının doldurulması, sazlıkların yakılması ve havaalanı gibi faaliyetlerden ötürü kısmen parçalanmış durumdadır. Diğer çekirdek alanlarda Sıhke Göleti ve doğal akarsu koridorlarının yakın çevrelerinde bulunmaktadır. Alanlar ise; genel olarak tarım alanlarını, çayır- mera alanlarını, atıl alanları, herhangi bir alan kullanımı olmayan boş alanları, kırsal yerleşmeleri içermektedir. Çalışma alanda doğal akarsu koridorları dışında kalan alanlarda çoğunlukla YAB bakımından uygun olmayan kent merkezindeki kentsel yerleşimleri kapsamaktadır. Çalışma alanın \% 50'nden fazlasını kaplayan alanların büyük çoğunluğu çalışma alanının kuzeyinde bulunmaktadırlar. Alanlar çekirdek alanlara kıyasla daha az parçalanmış durumda olup çalışma alanının kuzeydoğusu, kuzey batısı ve kuzeyinden iç kesimlere doğru geniş bir alanı kaplamaktadırlar. Koridor olarak belirlenen doğal akarsu koridorları; Çayarası Deresi (Akköprü Deresi), Karasu Çayı, Morallı Deresi ve Kurubaş Deresi, Bakraçlı Deresi, Şahmuran Kanalı'dır. Belirlenen doğal akarsu koridorları çalışma alanının bir ucundan diğerine kesintisiz bir şekilde akmaktadır. Doğal akarsu koridorları YAB'nin içinden geçerek Van Gölü kıyısında sazlık-bataklık alanlarla birleşmektedir. Akarsuların yakın çevresinde bulunan sazlık-bataklık alanların doğal akarsu koridorları aracılığıyla Van Gölü kıyısındaki sazlık- bataklık alanlarla birleşmesi önemlidir. 
Şekil 2.15 Van Kent Merkezi ve Yakın Çevresinin YAB Bakımından Uygunluk Durumu

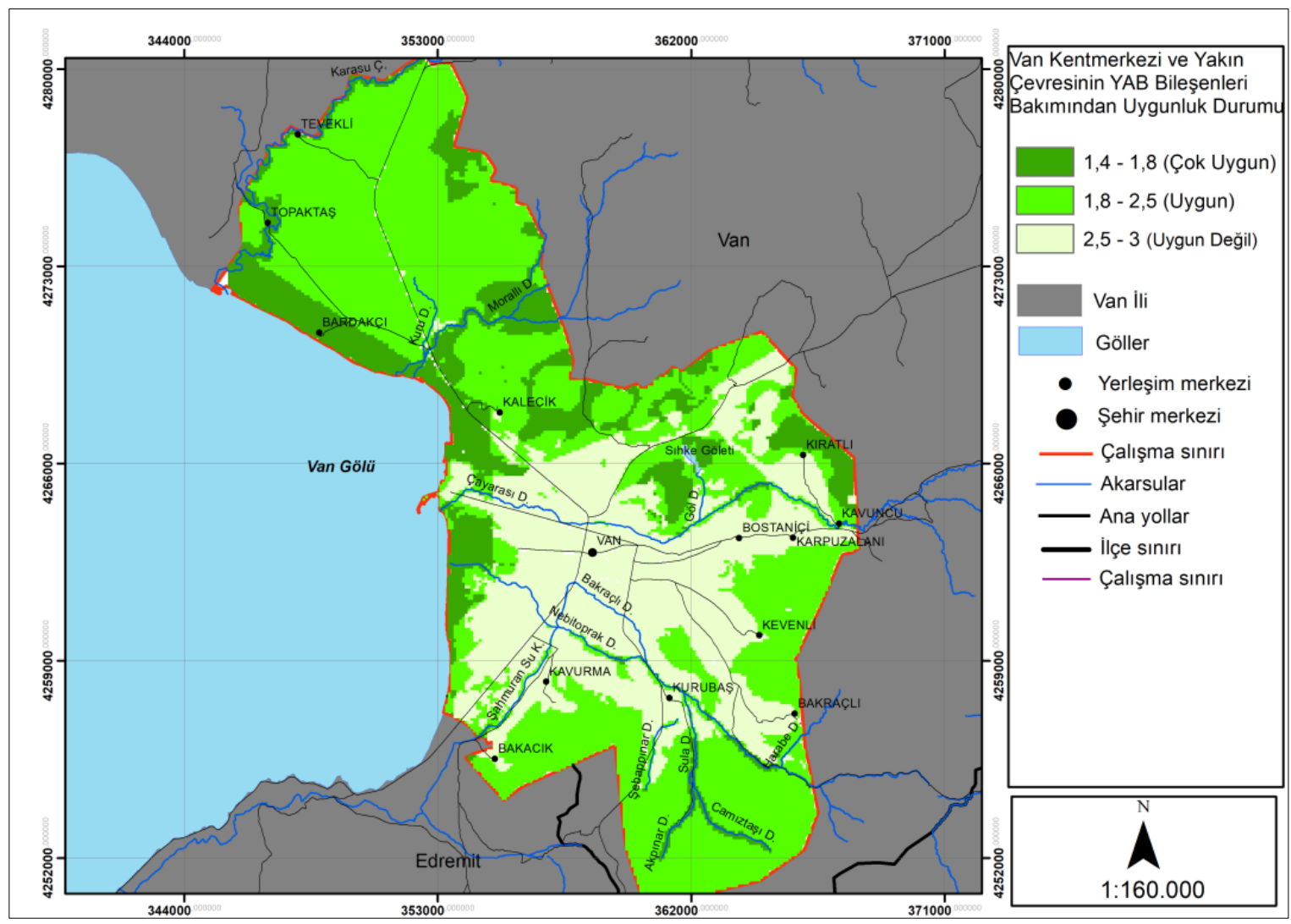

Kaynak: Yazarlar tarafından oluşturulmuştur. 
Şekil 2.16 Van Kent Merkezi ve Yakın Çevresinde Çekirdek Alanlar

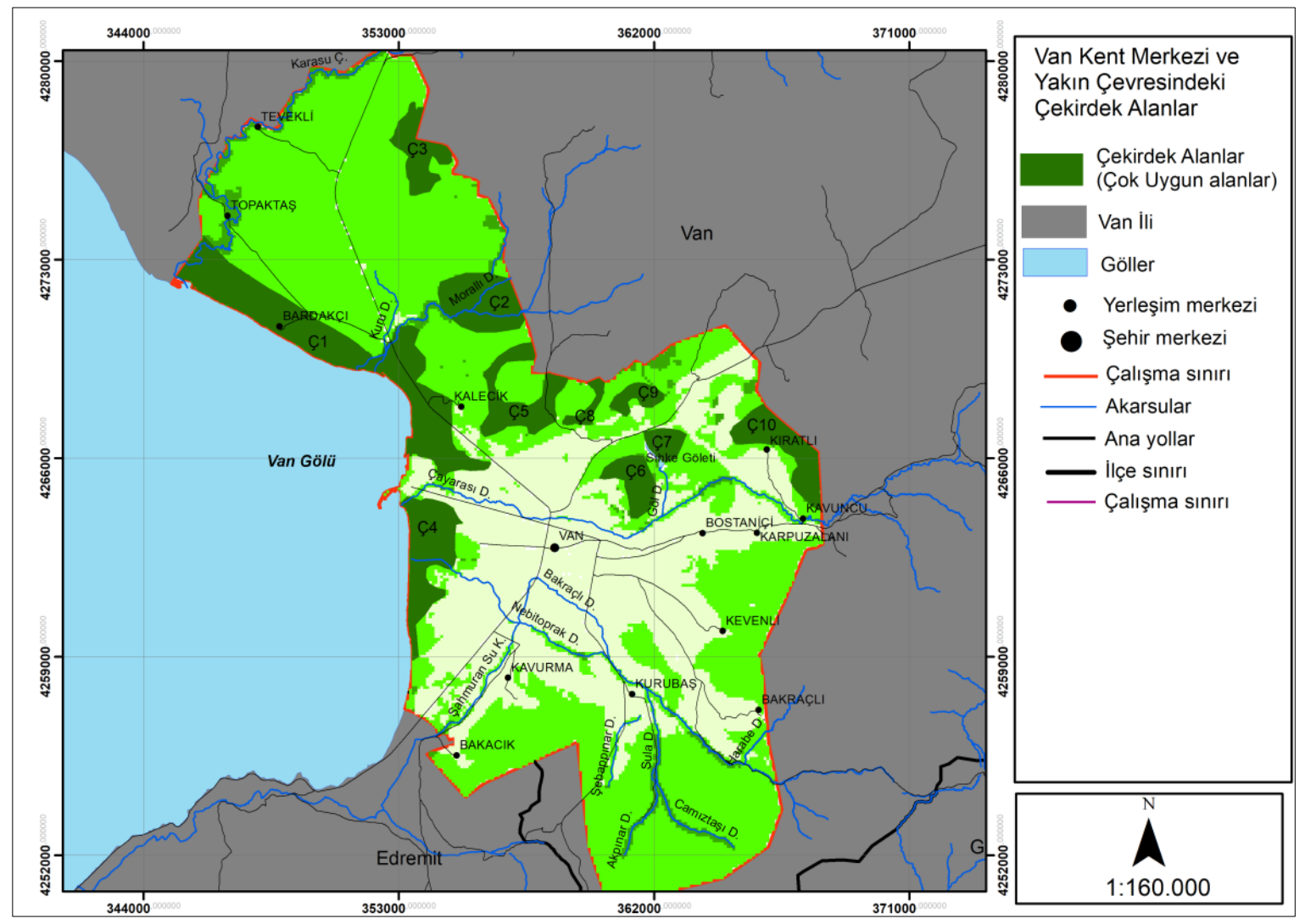

Kaynak: Yazarlar tarafından oluşturulmuştur.

Tablo 2.6 CBS araçları ile belirlenen YAB

\begin{tabular}{|c|c|}
\hline \multicolumn{2}{|c|}{ CBS araçları ile belirlenen YAB } \\
\hline \multicolumn{2}{|c|}{ Çekirdekler } \\
\hline Ç1 & $\begin{array}{l}\text { Çalışma alanının batısında, } 1627 \text { ha büyüklüğünde, Van Gölü kıyısında kent merkezine doğru } \\
\text { uzanmaktadır. }\end{array}$ \\
\hline Ç2 & $\begin{array}{l}\text { Çalışma alanının kuzeydoğusunda, } 508 \text { ha büyüklüğündedir. Morallı ve Osmangöl Derelerini içine } \\
\text { almaktadır }\end{array}$ \\
\hline Ç3 & $\begin{array}{l}\text { Çalışma alanının kuzeydoğusunda } 427 \text { ha büyüklüğündedir. K1 ve K2 olarak belirlenen Karasu Çayı ve } \\
\text { Osmangöl derelerini içine almaktadır. }\end{array}$ \\
\hline Ç4 & $\begin{array}{l}539 \text { ha büyüklüğünde çalışma alanının batı kısmında Van Gölü kıyısında bulunmaktadır. Ç4 içinde; Van } \\
\text { Kalesi 1.Derece DSA, Van Kalesi 1. Derece ASA, Van Kalesi 2. Derece ASA ve Van Kalesi 3. Derece } \\
\text { ASA yer almaktadır. }\end{array}$ \\
\hline Ç5 & $\begin{array}{l}\text { Çalışma alanının kuzeydoğusunda Kalecik yerleşim alanı civarında bulunmakta ve } 427 \text { ha } \\
\text { büyüklüğündedir }\end{array}$ \\
\hline Ç6 & $\begin{array}{l}\text { Çalışma alanının iç kısımlarında kent merkezine yakın bir konumda bulunmakta ve } 241 \text { ha } \\
\text { büyüklüğündedir }\end{array}$ \\
\hline Ç7 & $\begin{array}{l}\text { Sıhke Göleti ve çevresinde belirlenmiş olup, } 129 \text { ha büyüklüğündedir. Konum olarak; Ç7, Ç6, ve Ç11'in } \\
\text { ortasında, A8, A6 ve A10'a yakın bir konumda bulunmaktadır. }\end{array}$ \\
\hline
\end{tabular}




\begin{tabular}{|c|c|}
\hline Ç8 & $\begin{array}{l}\text { Çalışma alanının kuzeydoğusunda, Ç5 ve Ç9'un ortasında yer almakta ve } 80 \text { ha büyüklüğündedir. Ç8 } \\
\text { konu olarak aynı zamanda A5 ve A6'nında ortasında yer almaktadır }\end{array}$ \\
\hline Ç9 & $\begin{array}{l}\text { Çalışma alanının kuzeydoğusunda yer almakta ve } 125 \text { ha büyüklüğündedir. Konum olarak Ç7, Ç8 ve } \\
\text { Ç9'un ortasında ve A6'ya yakın bir konumdadır. }\end{array}$ \\
\hline Ç10 & Çalışma alanının en doğu ucunda Kıratlı yerleşim alanı civarında bulunmakta ve 414 ha büyüklüğündedir. \\
\hline \multicolumn{2}{|c|}{ Alanlar } \\
\hline A1 & $\begin{array}{l}\text { Çalışma alanının kuzeyinden iç kısımlara doğru geniş bir alan kaplamakta ve } 6065 \text { ha büyüklüğündedir. } \\
\text { Çalışma alanındaki en büyük alan olan A1, Topraktaş, Tevekli, Bardakçı yerleşim alanları civarındadır. }\end{array}$ \\
\hline $\mathrm{A} 2$ & $\begin{array}{l}\text { Çalışma alanının kuzeybatısında, K1olarak belirlenen Karasu çayı ve Ç1'e yakın konumda olup } 118 \text { ha } \\
\text { büyüklüğündedir. }\end{array}$ \\
\hline A3 & Çalışma alanın iç kısımlarında, Ç1, Ç5,Ç2 ve A1'in ortasında yer almakta olup 929 ha büyüklüğündedir. \\
\hline A4 & $\begin{array}{l}\text { Çalışma alanının kuzeydoğusunda, Ç5'in etrafinı sardığı bir konumda bulunmakta ve } 210 \text { ha } \\
\text { büyüklüğündedir. }\end{array}$ \\
\hline A5 & Çalışma alanının kuzeydoğusunda, Ç5 ve Ç8'in ortasında yer almakta olup 372 ha büyüklüğündedir. \\
\hline A6 & Çalışma alanının kuzeydoğusunda, Ç8, Ç7, Ç9'a yakın bir konumda olup, 716 ha büyüklüğündedir. \\
\hline A7 & Van Gölü kıyısına yakın bir konumda Ç1 ve Ç4 arasında bulunmakta ve 51 ha büyüklüğündedir. \\
\hline A8 & Çalışma alanının batısında, Ç4’e yakın bir konumda ve 620 ha büyüklüğündedir. \\
\hline A9 & $\begin{array}{l}\text { Çalışma alanının doğusunda Kıratlı yerleşim alanına yakın bir konumda bulunur ve } 177 \text { ha } \\
\text { büyüklüğündedir. }\end{array}$ \\
\hline A10 & $\begin{array}{l}\text { Kavuncu yerleşim alanından Kıratlı yerleşim alanına ve A9'a doğru uzanmakta ve } 258 \text { ha } \\
\text { büyüklüğündedir. }\end{array}$ \\
\hline A11 & Çalışma alanının iç kısımlarında, Ç6'ya yakın bir konumda bulunmakta ve 99 ha büyüklüğündedir. \\
\hline A12 & $\begin{array}{l}\text { Çalışma alanının batısında, Van Gölü kıyında ve Ç4 ile A13'e yakın bir konumda ve171 ha } \\
\text { büyüklüğündedir. }\end{array}$ \\
\hline A13 & Çalışma alanının güneybatısında, A14 ve A12 arasında bulunmakta ve 217 ha büyüklüğündedir. \\
\hline A14 & $\begin{array}{l}\text { Çalışma alnının güneyini kaplayan, Bakraçlı, Kavurma, Bakacık ve Kurubaş yerleşim alanları yakınında } \\
\text { bulunmakta ve } 4629 \text { ha büyüklüğündedir. }\end{array}$ \\
\hline A15 & $\begin{array}{l}\text { Çalışma alanının doğusunda, Kevenli, Karpuzalanı ve Bakraçlı yerleşim alanlarına yakın bir konumda } \\
\text { bulunmakta ve } 1477 \text { ha büyüklüğündedir. }\end{array}$ \\
\hline A16 & $\begin{array}{l}\text { Çalışma alanının iç kısımlarında, Kurubaş, Kevenli ve Bakraçlı yerleşim alanlarının ortasında bulunmakta } \\
\text { ve } 262 \text { ha büyüklüğundedir. }\end{array}$ \\
\hline \multicolumn{2}{|c|}{ Koridorlar } \\
\hline $\mathrm{K} 1$ & $\begin{array}{l}\text { Çalışma alanının kuzeyi boyunca batıya doğru akmakta olan Karasu Çayı'dır. Çalışma alanındaki } \\
\text { uzunluğu } 21 \mathrm{~km} \text { uzunluğundadır. }\end{array}$ \\
\hline $\mathrm{K} 2$ & Çalışma alanının kuzeydoğusunu batısı ile birleştiren Morallı Deresidir. 17 km uzunluğundadır. \\
\hline K3 & Çalışma alanının doğu ucunu ve batı ucuna doğru kesintisiz bir şekilde akan, 17 km uzunluğundadır. \\
\hline K4 & nının güney doğusundan batı ucuna doğru akmakta ve 16 km uzunluğundadır. \\
\hline
\end{tabular}

Kaynak: Yazarlar tarafindan oluşturulmuştur 
Şekil 2.17 Van Kent Merkezi ve Yakın Çevresindeki Alanlar

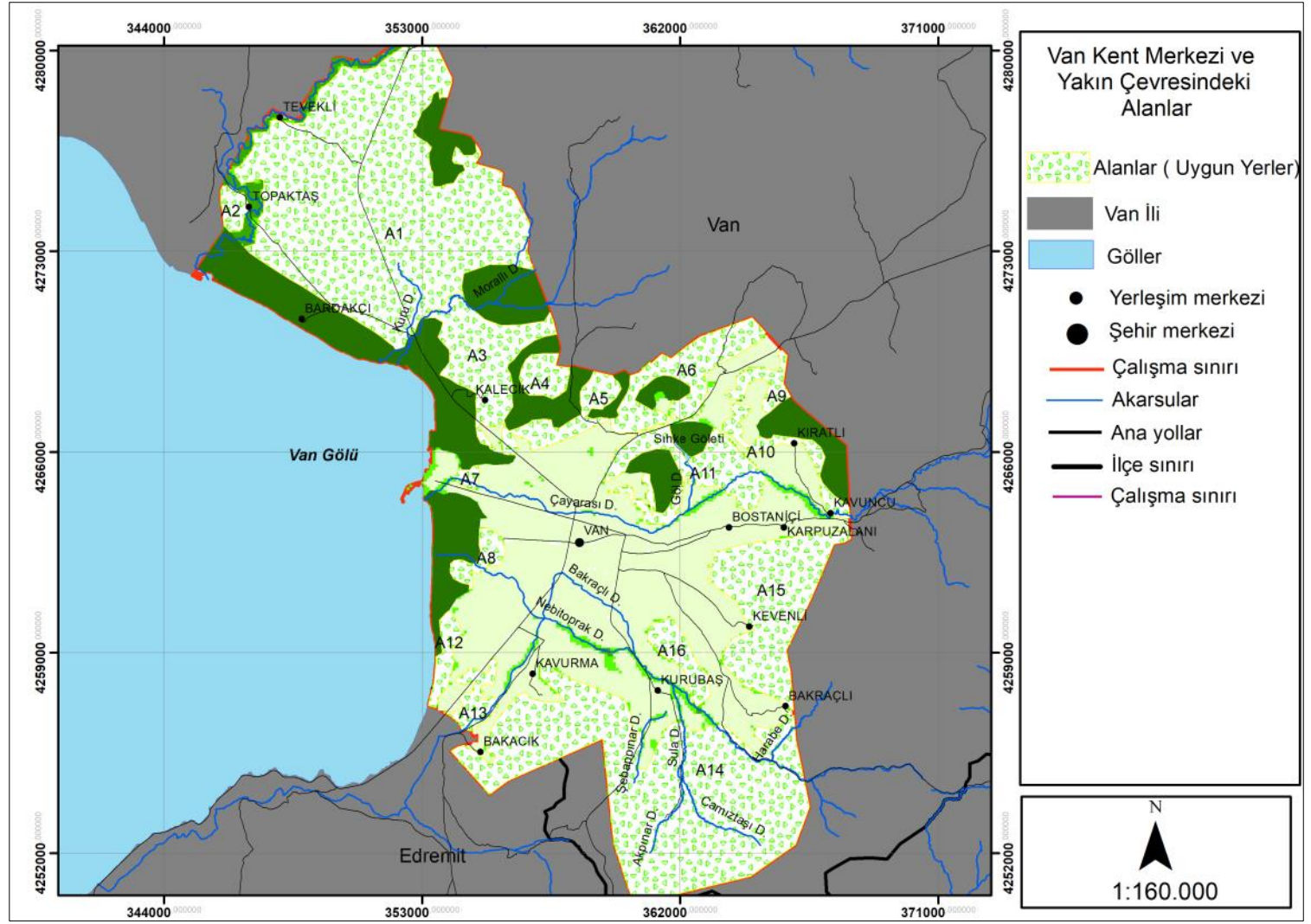

Kaynak: Yazarlar tarafindan oluşturulmuştur 
Şekil 2.18 Van Kent Merkezi ve Yakın Çevresindeki Doğal Akarsu Koridorları

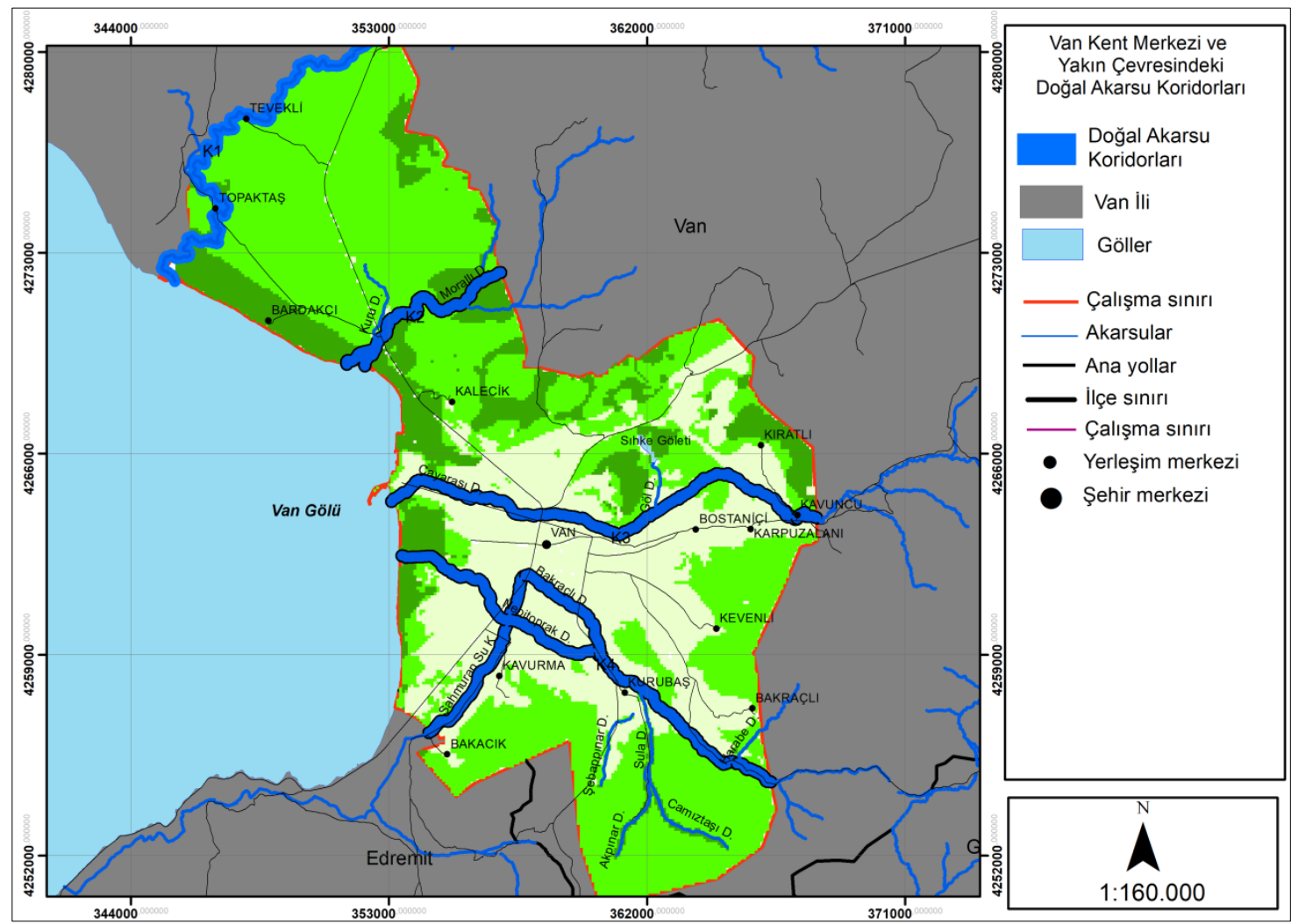

Kaynak: Yazarlar tarafından oluşturulmuştur

\section{SONUÇ}

Van Kent merkezi ve yakın çevresinde yeşil altyapı bileşenlerinin CBS araçları ile tanımlanması' kapsamında yapılan bu çalışmada amaç; Van Kent merkezi ve yakın çevresindeki YAB bakımından uygunluk durumu ortaya konularak YAB belirlenmiştir. Bu kapsamda yapılan analizler sonucunda kent merkezi ve yakın çevresinde 10 çekirdek alan, 16 alan ve 4 koridor belirlenmiştir. Çalışma alanındaki belirlenen bu bileşenlerin genel dağılımı; bileşenlerin büyük bir bölümünün çalışma alanının kuzeyinden iç kısımlara doğru, güneyinde, kuzey doğusunda ve batısında yani Van Gölü kıyısında bulunmaktadır. Van kent merkezinde herhangi bir alan veya çekirdek bulunmamakla birlikte, koridor olarak belirlenen bileşenler kent merkeziden geçerek Van Gölü’ne dökülmektedirler.

Çalışma alanının merkezini oluşturan Van Kent merkezi YAB bakımından oldukça zayıftır. Bunun başlıca sebepleri; kentsel yayılmadır. Bilinçsizce ve doğal kaynak koruma süreçlerini göz ardı eden kentsel yayılma kent merkezini yeşil alanlar bakımından dolayısıyla YAB bakımından oldukça güçsüz kılmıştır. Bunun aksine kent merkezinden uzaklaştıkça YAB özelliği gösteren açık yeşil alan uygulamaları; tarım alanları, bağ-bahçelik alanlar, çayır-mera alanları, sulak alanlar gibi alan kullanımları artmaktadır. Özellikle Van gölü kıyısında ve akarsuların yakın çevresinde bulunan sazlık- bataklık alanlar YAB için önemli çekirdek alanlardır. Ancak arazi gezilerinde yapılan gözlemler sırasında çalışma alanının kullanıcı baskısı altında olduğu görülmüştür. Mevcut durumu göz önüne alındığında kent merkezinin YAB bakımından oldukça kötü bir durumda olduğu görülmektedir. Özellikle Van gibi hızlı büyüyen ve 1.500.000'dan fazla nüfusu olan bir kent için bu durum gelecekte ciddi bir soruna işaret etmektedir. Yoğun kullanıcı kitlesine rağmen kent merkezinde kullanıcıların ihtiyacını karşılayacak yeterli sayıda açık-yeşil alanlar bulunmamaktadır. Bundan dolayı ekolojik olarak kent 
ihtiyacı sosyal olarak kullanıcıların YAB bakımından ihtiyaçları karşılanmamaktadır. Bu durumda yerel yönetimlere ve ilgili kuruşlara büyük sorumluluklar yüklenmektedir. Özellikle planlama yaklaşım ve stratejilerinde doğal kaynak koruma ve kullanım dengesinin göz önüne alınması, doğal kaynak kullanımı konusunda alan kullanıcılarının bilinçlendirilmesi, doğal ve kültürel peyzaj alanlarının korunmasına ilişkin caydırıcı yasal önlemlerin alınması gibi sorumluklular bu kapsamda ele alınması gereken önemli başlıklardır.

Van Kent merkezi ve yakın çevresinin YAB bakımından mevcut durumunun ortaya konulmasında; CBS araçları aktif olarak kullanılarak çalışmanın güvenilirliği artırılmış, çalışma sistematik bir düzende yapılmış, zaman tasarrufu açısından önemli kolaylıklar sağlamıştır. Bu da kente dair yapılacak olan planlama stratejilerinde CBS araçlarının sağladığı yararlar açısından oldukça önemlidir. Kent bilgi sistemlerinin önemli bir bileşeni olan CBS yerel yönetimlerin; planlama ve koruma yaklaşım ve modellerinde, alan kullanım kararlarında ve sosyo-ekonomik faaliyetlerinde oldukça kolaylıklar sağlamaktadır. Çalışmada CBS araçları ve sağladığı yararlar belirtilerek yerel yönetimlerin bu konudaki duyarlılığını artırmak ve CBS araçlarının kullanımını teşvik etmektir. Çalışma kapsamında yapılan analizler; vektör verilerin raster veriye dönüştürülmesi, raster verilerin yeniden sınıflandırılması, sınıflandırılan verilerin ağırlıklandırılarak çakıştırılması ve sonuç olarak Van Kenti ve yakın çevresinin YAB bakımından mevcut durumunun ortaya konulmasıdır. Bu analizlerin CBS ortamında yapılması çalışmanın güvenilirliğini artırmaktadır. Bu analizler CBS ortamında değil de başka ortamlarda veya farklı yöntemlerle yapılsaydı güvenilirlik, düzen ve sistematik oluşu açısından ve zaman tasarrufu açısından farklı sonuçlar ortaya çıkmış olacaktı. Çalışma kapsamında veri toplama ve verilerin elde edilmesi sürecinde sıkıntılar yaşanmıştır. Bunun sebebi Van Kent Bilgi Sistemi'nin yeni olması ve altyapısının yeterli olmamasıdır. Aslında bir büyükşehir olan Van Kenti için bu durum sorun oluşturmaktadır. Ancak zamanla bu durumun geliştirilmesi ve kent bilgi sisteminde CBS araçlarının aktif kullanımı daha aktif bir hal alması bu sorunu ortadan kaldırmak için önemli bir yöntemdir. Bu nedenle CBS'nin yerel yönetim faaliyetlerinde kullanılması oldukça önemlidir. CBS araçları kullanılarak yapılan bu çalışma Van Kent'i için literatür açısından önemli bir yeşil altyapı kaynağı oluşturmaktadır. Daha önce bu alanda herhangi bir çalışma yapıılmamış olmaması çalışmanın önemini ayrıca artırmaktadır. Özellikle alan kullanım kararlarında ve imar uygulamalarında yerel yönetimlerin yeşil altyapıyı göz önüne alan kararlar vermesi ve kentsel açık yeşil alan uygulamalarında CBS araçlarının kullanılması bakımından önemlidir.

Sonuç olarak; Van Kent merkezi ve yakın çevresinde YAB belirlenmesi kapsamında CBS araçları kullanılarak mevcut durum ortaya konulmuştur. YAB olan; çekirdek, alan ve doğal akarsu koridorlarının nitelikleri ve barındırdıkları alan kullanımları ortaya konulmuştur. Van Kent merkezi için bu durumun iç açıcı olmadığı ve önlem alınmadığı takdirde gelecekte daha büyük sorunlara yol açacaktır. Çalışma sırasında Kent Bilgi Sistemi’nin altyapısının yeterli olmamasından ötürü karşılaşılan sorunlar çalışmanın niteliğini olumsuz etkilemiştir. Tüm bu süreçler ve alan çalışmaları göz önüne alındı̆̆ında; Van Kent Bilgi Sistemi’nin güçlendirilmesi ve yerel yönetimlerin daha aktif bir şekilde bu sistemleri kullanması gereklidir. Yerel yönetimlerin Kent Bilgi Sistemi içinde yer alan CBS araçlarını daha aktif kullanması ve altyapısını bu bakımdan güçlendirmesi gelecekte yapılacak olan çalışmaları kolaylaştıracak ve çalışmaların niteliğini artıracaktır. 


\section{KAYNAKÇA}

Ahern, J. (1995), 'Greenways as a planning strategy', Landscape and urban planning, Volume 33, No 1-3, pp. 131-155.

Andersson, E. (2014), et al. 'Reconnecting cities to the biosphere: stewardship of green infrastructure and urban ecosystem services', Ambio, Volume 43, No 4, pp. 445-453.

Benedict M. A., McMahon Edward, T. (2006), Green infrastructure, Island Press, pp. 7-15.

Bennett, G. (2004). 'Linkages in practice: a review of their conservation value'. IUCN, pp. 3-11.

Coşkun Hepcan, Ç. (2008), Doğa Korumada Sürdürülebilir Bir Yaklaşım, Ekolojik Ağların Belirlenmesi ve Planlanması, Basılmamış Doktora Tezi, Ege Üniversitesi, Fen Bilimleri Enstitüsü, İzmir.

Hoctor T. S. (2003) Regional Landscape Analysis And Reserve Design To Conserve Florida's Biodiversity, $\mathrm{PhD}$ Thesis, University of Florida, Florida.

Jongman Rob, HG., Pungettı G. et al. (2004), Ecological networks and greenways: concept, design, implementation, Cambridge University Press, pp. 12.

Kapluhan, E. (2014), 'Coğrafi Bilgi Sistemleri'nin (CBS) coğrafya öğretiminde kullanımının önemi ve gerekliliği’, Marmara Coğrafya Dergisi, Sayı 29, ss. 34-59.

Kopperoinen, L., Itkonen, P., Niemela, J. (2014), 'Using expert knowledge in combining green infrastructure and ecosystem services in land use planning: an insight into a new place-based methodology', Landscape Ecology, Volume 29, No 8, pp. 1361-1375.

Lovell, S. T., Taylor, J. R. (2013), 'Supplying urban ecosystem services through multifunctional green infrastructure in the United States', Landscape Ecology, Volume 28, No 8, pp. 1447-1463.

Mell, I. C. (2009), 'Can green infrastructure promote urban sustainability? In: Proceedings of the Institution of Civil Engineers-Engineering Sustainability’, Thomas Telford Ltd, Volume 162 No 1, pp. 23-34.

Özeren, M. (2012), Yeşil Altyapı Sistemi Kapsamında Meles Deltası ve Çevresinin Kurgulanması. Basılmamış Yüksek Lisans Tezi, Ege Üniversitesi, Fen Bilimleri Üniversitesi, İzmir.

Sandstrom, U. G. (2002), 'Green infrastructure planning in urban Sweden', Planning practice and research, Volume 17, No 4, pp. 373-385.

Van Büyükşehir Belediyesi (2016), Imar ve Şehircilik Müdürlüğü CBS verileri.

Weber, T., Sloan, A., Wolf, J. (2006), 'Maryland's Green Infrastructure Assessment: Development of a comprehensive approach to land conservation', Landscape and Urban Planning, Volume 77, No 1-2, pp. 94110.

Wu, J. (2013), 'Landscape Sustainability Science: Ecosystem Services and Human Well-Being in Changing Landscapes', Landscape Ecology, Volume 28, No 6, pp. 999-1023. 